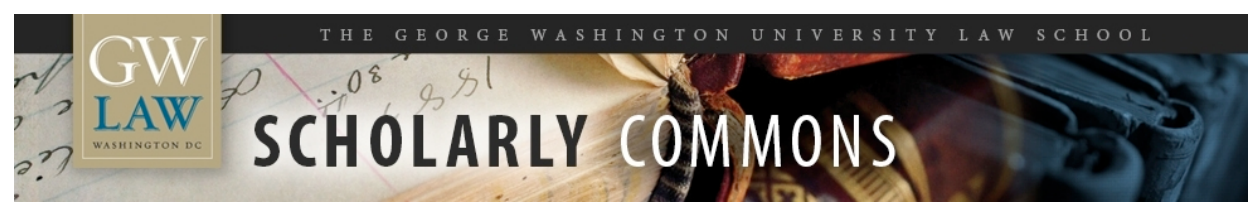

\title{
Domestic Violence, Character, and Social Change in the Welfare Reform Debate
}

\author{
Joan S. Meier \\ George Washington University Law School, jmeier@law.gwu.edu
}

Follow this and additional works at: https://scholarship.law.gwu.edu/faculty_publications

Part of the Law Commons

\section{Recommended Citation}

Joan S. Meier, Domestic Violence, Character, and Social Change in the Welfare Reform Debate, 19 L. \& Pol'y 657 (1997).

This Article is brought to you for free and open access by the Faculty Scholarship at Scholarly Commons. It has been accepted for inclusion in GW Law Faculty Publications \& Other Works by an authorized administrator of Scholarly Commons. For more information, please contact spagel@law.gwu.edu. 


\title{
Domestic Violence, Character, And Social Change In The Welfare Reform Debate
}

\author{
JOAN MEIER*
}

This article addresses the recently discovered connection between domestic violence and welfare "dependency." Empirical research among welfare populations shows that over $50 \%$ of women receiving welfare are or have recently been battered, and that partner abuse is a major reason for the continuing poverty of many women.

The question the author asks and begins to answer is why this connection has not previously been identified or publicized by either the battered women's movement or the anti-poverty movement, and what the challenge may be to both movements as they attempt to address it in the context of welfare reform. The author argues that the connection has not been previously addressed because of the somewhat conflicting ideologies underlying both movements. The battered women's movement is defined in part by its strong moral denunciation of male abusers and assertion of the victimization of women by men. The anti-poverty movement is reluctant to demonize half of the poor population, particularly in light of the conservative welfare reformers' emphasis on "character" as the main cause of poverty. The article argues that we must - and can - find a way to synthesize the feminist emphasis on interpersonal justice and morality with the anti-poverty movement's recognition of the larger social causes of poverty. The perspectives of both movements must be enlarged to recognize the multiple layers of victimization which poor women and men endure; and both movements will be revitalized by this cross-fertilization.

* Professor of Clinical Law and Director of Domestic Violence Advocacy Project, The George Washington University Law School. I would like to express my thanks to Jody Raphael, Director, Taylor Institute, both for her pioneering work in this field and for her early and consistent enthusiasm for my work on this essay. (All flaws are mine alone.) Thanks also to those often unsung advocates who have toiled to increase protections for battered women in the context of welfare reform, and particularly to Shirley Traylor, executive director of Harlem Legal Services, for her pioneering work on violence against African-American women. In addition I thank Naomi Cahn, Martha Davis, Jill Davies, Chip Lupu, Peter Margulies, Jody Raphael, Paul Tremblay, Louise Trubek, Joan Zorza and two anonymous peer reviewers for their thoughtful comments on an earlier draft. Finally, I am grateful to The George Washington University Law School for its financial support of this research through the summer grant program. Portions of this article were first conceptualized and presented in oral comments on an early draft of the article by Peter Margulies, cited infra n. 46, at the "Symposium on Community, Pluralism, and Professional Responsibility" at The George Washington University Law School in February 1995.

Address correspondence to Joan Meier, George Washington University Law School, National Law Center, 2000 H Street, NW, Washington, D.C. 20052. Telephone: (202)994-7463; e-mail: JoanS@clinic.nlc.gwu.edu. 


\section{INTRODUCTION}

In the past two years of rapid activity concerning welfare reform, a small but growing chorus of activists in the anti-poverty and feminist movements have focused attention on the relationship between domestic violence and the poverty of women and children (Raphael 1995, 1996a, 1996c, 1997; Davis \& Kraham 1995). ${ }^{1}$ While it is no surprise that some women become "poor" and in need of welfare when they separate from an abuser, another aspect of the link between domestic violence and welfare has been less well-understood, and has more fundamental implications for the continuing debate: For women seeking to get off welfare, the path from "welfare-to-work" is frequently obstructed by abusive male partners. Such partners interfere with women's employment both directly, when they seek to prevent "their" women from gaining independence, and indirectly, when the secondary effect of domestic violence, that is, traumatization, prevent or greatly burden women's abilities both to work and care for their children (Raphael 1996a: 6-9). ${ }^{2}$ Perhaps even more striking is the fact that this connection between welfare dependency ${ }^{3}$ and battering is far from rare: a series of recent studies have found with surprising consistency that $15 \%$ to $30 \%$ of welfare recipients are current - and a staggering $50 \%$ to $60 \%$ are past (as adults) - victims of domestic violence (Raphael 1995, 1996a; Raphael \& Tolman 1997: 20-21).

The link between battering and welfare has critical implications in this era of radical reform of welfare. Although we do not know precisely what percentage of battered women on welfare are there because of battering, the qualitative data documenting batterers' intentional sabotage of women's work efforts described in Section I below persuasively suggest that the link is not merely correlative, but is often also causal. At a practical policy level, this suggests that many of the stringent restrictions on public assistance, such as time limits, work requirements, residency restrictions, and others which the conservative ${ }^{4}$ movement for welfare reform has succeeded in incorporating into the federal Personal Responsibility and Work Opportunity Act of 1996 ("PRA"), may threaten the survival of many battered women and children for whom the only choices may be welfare or physical abuse (Davis \& Kraham 1995: 3-5, 13-24). At a more ideological level, the data challenge the reformers' moral critique of welfare and welfare recipients, that is, their beliefs that individuals' poverty is the result of a failure of character and moral virtue, reflected in laziness, lack of responsibility, substance abuse, and dependency on welfare. ${ }^{5}$ Implicit in the conservative critique is the assumption that many of the purportedly dysfunctional actions of the poor are freely "chosen," rational responses to the distorted incentives created by the availability of public assistance. However, the fact that many women depend on welfare because of men's intentional abuse potentially counters the widespread view that many women live off welfare purely because of their own failures of moral fibre or character. ${ }^{6}$ 
At the same time, the new documentation of the linkage between battering and welfare raises a pressing question for thinkers and activists for the poor and for battered women. To many such as myself who work with poor battered women, while the statistics are somewhat surprising, the fact of the overlap between domestic violence and poverty is not. As longstanding participants in or observers of the battered women's and/or anti-poverty movements, ${ }^{7}$ we must then ask: why has this connection been ignored by activists of both movements for so long? ${ }^{8}$ There can be no doubt that there has been a historic disconnection between these movements: On the poverty advocacy side, it has been argued that both legal services lawyers and poverty theorists have marginalized family law in general, and domestic violence in particular (Margulies 1996: 1071). Conversely, until recently very little of the now voluminous scholarship, policy analysis, and activism against battering addressed the relevance of poverty to domestic violence. ${ }^{9}$ However, at root, it is my contention that the rift between these movements is due to more than mere historical happenstance or sexism; rather it is partly the product of a fundamental philosophical or ideological conflict between the philosophies and values of the two movements. It is this gulf which advocates for both the poor and battered women must now face: The insufficient integration of feminist - specifically domestic violence perspectives into poverty advocacy, and of poverty concerns into advocacy for battered women, is in part what has allowed the nation's political culture to become so hostile to poor welfare mothers. The current welfare reform "crisis," which threatens the safety and well-being of many women and children, and which could not have occurred without the widespread belief that women on welfare are morally flawed, compels advocates from both the battered women's and poverty movements to come together on behalf of their poor constituents. Only when we understand the philosophical underpinnings of each movement and how they conflict, might we be able to move forward with new paradigms of both battering and poverty which can better answer the challenges of welfare reform.

This essay, then, explores the political and ideological ramifications both for policy and advocacy of the connection between domestic violence and poverty. I begin with a survey of the existing data, and a qualitative interpretation of those data to demonstrate a causal relationship between battering and welfare dependency. I discuss that relationship's implications for welfare reform policies and practices currently being considered or implemented under the PRA, as well as for the ideological premises of the welfare reform debate. I then examine its implications for the anti-poverty and battered women's movements themselves. I argue that the failure of activists and thinkers in the poverty and battered women's movements to address the interrelationship between domestic violence and poverty is due to a clash of ideologies that makes it difficult for their causes to be joined. The fundamental philosophy of the anti-poverty movement, the view that socioeconomic structural forces rather than individual bad character are tn 
blame for poverty and dysfunctional behavior, is difficult to integrate with the fundamental philosophy of the battered women's movement, which calls for moral judgment against batterers, including criminal sanctions as a means of "moral education" or "character reform." The battered women's movement's emphasis on male domination of women is uncomfortable for anti-poverty activists who are reluctant to demonize half of the poor population. Conversely, the battered women's movement has avoided focusing on domestic violence among the poor in favor of the "universalist" premise that domestic violence "cuts across race and class" and is a problem of sexist but universal, deeply-rooted norms condoning male domination of women. This movement has intentionally avoided discussing poverty in connection with domestic violence for fear that domestic violence would be viewed as "just another dysfunction of poor people," rather than the product of widely held sexist social and legal norms. Meaningful acknowledgment of the interaction between poverty and domestic violence thus threatens the fundamental tenets of both movements.

Ultimately I argue that the current welfare reform crisis demands that the battered women's and poverty movements join forces, incorporate the lessons of each, and reach a more unified position on the interaction of poverty and domestic violence. Such a synthesis is critical as a practical matter in policy development if poor victims of domestic violence are not to be put at even greater risk of violence by governmental welfare policies. Integration of the moral significance of domestic violence for welfare recipients is also the most effective weapon the Left currently has to counter the moral judgments against welfare mothers that are fueling the harshest aspects of welfare reform. While the current attack on the poor is unwarranted and unfair, welfare policy always has been and probably always will be in part a debate about gender roles, family structure and moral desert. ${ }^{10}$ That inherently moral debate needs to be informed by feminist, progressive values if there is to be some hope of achieving a more constructive perspective on the poverty and welfare crisis. The Left's alternative - refusal to engage in the moral debate - has simply meant abdicating the field to the conservative reformers.

Moreover, such a synthesis is also theoretically and philosophically compelled for both the battered women's and anti-poverty movements themselves. As a matter of intellectual honesty, both must come to terms with the increasingly prevalent data (both in welfare studies and others) that suggest that rates of battering are higher for lower income women. And as a matter of political efficacy, both movements stand to be revitalized by meaningful integration of the other's concerns. Both movements have been accused of late of sterility and stagnation. ${ }^{11}$ The poverty movement's lack of convincing moral power and failure to counter the gender stereotypes upon which both the welfare system and its conservative critics have relied suggests that incorporation of a meaningful gender analysis may offer some needed re-fueling for the anti-poverty cause. By the same token, integration 
of poverty and economic issues into the battered women's movement's approach can only improve our effectiveness with clients and communities of different classes and races; it may also offer a more sophisticated, nuanced approach to replace the simplistic stereotypes which have been destructive to many abused women and the cause as a whole. ${ }^{12}$

\section{A BRIEF OVERVIEW OF THE LINKS BETWEEN DOMESTIC VIOLENCE, POVERTY, AND WELFARE DEPENDENCY}

Starting in 1995, the connection between domestic violence and the unemployment of poor women began to be brought to light in large part by the efforts of Jody Raphael, director of the Taylor Institute, a Chicago research institute devoted to "research for real change." In her first series of reports, Raphael $(1995,1996 \mathrm{a}, 1996 \mathrm{c})$ summarized the results of several surveys taken of different welfare-to-work programs around the country. Her findings surfaced two previously unacknowledged phenomena among the welfare population: first, the typical welfare recipient, contrary to widespread assumptions, is not a single female head of a household. ${ }^{13}$ More often than not, female AFDC recipients are, at least intermittently, involved with men, many of whom are physically and emotionally abusive. ${ }^{14}$ Second and more importantly, abusive men, who are typically motivated by a need to possess and control their partners, frequently intentionally sabotage their partners' steps toward economic betterment in order to keep their partners dependent on - or at least not better than - themselves.

The surveys found that both welfare-to-work programs and welfare recipients themselves have identified many examples of such interference, such as the following: abusers administer a beating the night before a major exam or job interview, offer to drive the partner to an employment interview and then fail to do so, harass or stalk them at the job, or call the employer to badmouth the partner so she will be fired. Some tear up the woman's school assignments, hide their winter coats, and slash their tires (Raphael 1995, 1996a). Such measures typically produce their intended result: the woman is forced out of the employment, training or educational program, and back onto welfare, and sometimes, financial dependency on her abuser. A significant portion of these sabotaging activities occur after the woman has separated from her abuser (Raphael 1995, 1996a: 4-9). ${ }^{15}$

Raphael's early efforts were followed by a series of more comprehensive studies in several states, themselves summarized by Raphael and Professor Richard Tolman (Raphael \& Tolman 1997) from the University of Michigan: (i) a Passaic County, New Jersey, study of AFDC recipients in a welfare-to-work program; (ii) a Massachusetts study of (a random sample of) the state's welfare caseload; (iii) a several-year study in Worcester, Massachusetts, of 436 homeless and housed women, mostly on welfare; and (iv) a survey of women in one low-income neighborhood in Chicago. 
The data now available are both striking and strikingly consistent: they indicate that between $15 \%$ and $30 \%$ of welfare recipients are "currently"16 being physically abused, with three of the four studies coalescing around $15 \%$ to $20 \%$; and 34 to $65 \%$ of welfare recipients have been abused as adults, with three of the four studies coalescing around 57 to $60 \%$ (ibid. iii). ${ }^{17}$ Notably, these data are not dissimilar to at least some of Raphael's earlier findings. ${ }^{18}$

With respect to the relation between battering and employability, a University of Minnesota-Duluth study (Raphael 1996a: 15) found that among 123 women attending support groups for battered women, $55 \%$ had missed work, $62 \%$ had been late to work, and $24 \%$ had lost a job due in part to physical abuse. In addition, $50 \%$ reported that their male partners had discouraged them from working and going to school; with $38 \%$ "prohibited" from working and $25 \%$ prevented from going to school (ibid.). A recent study by the New York City Victims Services Agency (New York Dept. of Labor 1996: 3) found that $74 \%$ of employed battered women were harassed at work; $54 \%$ missed three days of work per month, and $56 \%$ were late at least five times per month. The New York Department of Labor Report (ibid.: 7) also reports a study by Schechter and Gray indicating that $20 \%$ of employed battered women typically lose their jobs due to domestic violence; and a survey by the New York State Department of Social Services finding that, among clients receiving services for domestic violence, $59.9 \%$ had left a job at some point due to battering.

In addition, the new welfare studies are beginning to empirically substantiate the anecdotal evidence indicating that abuse is often the direct cause of women's inability to become economically self-supporting: for example, the Passaic County study (Raphael \& Tolman 1997: 5) found that $39.7 \%$ of welfare recipients who are currently abused reported that their partner actively prevents their participation in education and training; only $12.9 \%$ of the non-abused recipients did so. The Massachusetts study found that abused women were "[10] times more likely than their never abused counterparts to have a current or former partner who would not like them going to school or work $(15.5 \%$ compared to $1.6 \%$ )" (ibid.: 8 ; Raphael 1997). The authors of the Worcester study, along with Raphael and Tolman (Raphael \& Tolman 1997: 12-13), draw similar inferences from their data, based on the high proportion of abuse victims in the sample as a whole, among those with longer welfare use, and among those who cycled on and off welfare (those who cycled also had more work experience). In short, the data point to the inference that abuse among the welfare population does not just pose "one more disadvantage" among the many disadvantages suffered by poor people. Rather, abuse often is aimed at and succeeds in stopping women from working or participating in education or training programs. It is important to note, however, that this does not suggest that battered women do not want to or are unable to work; but rather that abuse frequently disrupts and sabotages their employment. 
Domestic violence also obstructs poor women's ability to attain economic self-sufficiency indirectly, by causing traumatization and/or depression which can undermine some women's ability to concentrate and function productively in the work world. Some percentage of both current and former domestic violence victims suffer symptoms associated with posttraumatic stress disorder (PTSD) (Raphael 1996a: 9). The clinical concept of PTSD was first coined to describe the postwar sufferings of war veterans, and was subsequently found to apply to sufferers of traumatic violence, including family violence and sexual abuse (Herman 1992: 31-32). Symptoms of PTSD include chronic anxiety, memory loss, insomnia, dissociation or disconnection, nightmares, and flashbacks during which the person relives the trauma as if it were actually taking place (Dutton \& Goodman 1994: 217). These symptoms and the traumatization itself can severely inhibit concentration. It is also common for trauma sufferers to have difficulty planning for the future or believing in the future, and to avoid places or actions that they associate with the original violent trauma (Dutton 1993: nn. 183-88 and accompanying text; Herman 1992: 42; Raphael 1996a: 3, 9). ${ }^{19}$

Studies of battered women in shelters or receiving other services have found that as many as 60 to $80 \%$ of the sample experience symptoms of PTSD (Gordon 1996: 10-13; Kemp, et al. 1991, 1995; Saunders 1994). ${ }^{20}$ Typically, these symptoms are more likely when abuse is more severe and/ or unpredictable (Davies forthcoming: 16-17, citations omitted). With or without a diagnosed "disorder," women suffering from symptoms of trauma, such as flashbacks, nightmares, avoidance, and/or dissociation, are going to find the demands of new employment difficult at best (Raphael \& Tolman 1997: 6).

For example, if a welfare recipient was beaten because her abuser did not want her to go to work (where she might meet other men or decide she no longer needed him), she might be powerfully inhibited from pursuing another job in the future, even if her abuser is no longer present in her life. Similarly, a welfare recipient who is in a job or educational or training program and who suffers from PTSD might find herself unable to sleep because of the nightmares and flashbacks, and then be exhausted and unable to concentrate during the day. A recipient who is supposed to be seeking employment may be both sleepless and traumatized and unable to gather the motivation or hope to apply or interview for employment opportunities successfully. Many trauma survivors simply cannot concentrate enough to progress in their educational programs (Raphael 1996a: 7, 18). In some cases, the trauma and fear drive domestic violence victims to substance abuse as the only way to numb the pain and terror (Dutton 1993: 1221-22; Raphael 1996a: 4). In others, depression undermines motivation or ability to concentrate or work, and any belief in the future; in some cases, depression combined with the pressure and demands of obtaining employment causes victims to feel suicidal and sometimes to attempt suicide 
(Raphael \& Tolman 1997: 6; Raphael 1996a 3-5). In other words, an abuser need not be actively abusing his victim in order to obstruct her ability to obtain and retain employment. His abuse may continue to haunt her and undermine her functioning in the world even when he is no longer abusing her or is no longer in her life.

Thus, Raphael (1996c: 215-16; 1995: 8) has argued that the "culture of poverty" decried by many academics and policy analysts, evidenced in many AFDC recipients' “'learned helplessness,' apathy, resignation and inability to recognize and respond to new opportunity" (and, I would add, drug abuse, and "laziness"), may in fact be attributable to symptoms of PTSD and other reactions to violent terrorizing and abuse.

As for the question of the empirical evidence of the extent of this problem, of course knowledge is in its infancy (Raphael \& Tolman 1997: 23). However, while we do not yet have statistics that directly correlate PTSD and depression to domestic violence among the welfare population, the new welfare studies do provide some empirical, as well as anecdotal, support for the numerous anecdotal examples demonstrating that the mental health effects of abuse can create a barrier to employment: For instance, the Massachusetts study (ibid.: 8) found, based on a series of established psychological instruments, that abused women were "more likely to report a physical disability, handicap, or any other serious physical, mental or emotional problem" (i.e., $31.7 \%$ compared to $21.4 \%$ ). The Chicago study (ibid.: 15) found that whereas $25 \%$ of the total sample self-identified as depressed, $37 \%$ of the physically abused and $42.3 \%$ of the severely physically abused did so. The Worcester study (ibid.: 12) found that roughly $46.5 \%$ of welfare recipients suffered from a "major depressive disorder," and 35\% suffered from PTSD (three times the rate of the general population). Since approximately $32 \%$ of the study population had experienced severe physical violence within the past two years, and approximately $60.5 \%$ had ever experienced it as an adult, Raphael and Tolman (ibid.: ii) have concluded that it is very likely that some percentage of the depression and PTSD among the survey population is due to domestic violence. Finally, the Passaic County study found that $54 \%$ of the currently abused (compared to $32 \%$ of the whole sample) characterized themselves as "severely depressed"; and a standardized test found $66 \%$ of the entire sample to be depressed, with $11 \%$ "severely" depressed (ibid.: 5).

In short, while we do not currently know the precise numbers, it is clear that some proportion of public assistance recipients who have been abused (i.e., some subset of over $50 \%$ of recipients) may be suffering symptoms of trauma or depression which inhibit their ability to hold a job or participate in training or education. Not all of these people are currently being abused; some are suffering as adults the after-effects of past abuse. ${ }^{21}$ The implications of these realities for welfare policies is the subject of the next section. 


\section{IMPLICATIONS FOR WELFARE REFORM POLICIES OF THE LINKS BETWEEN DOMESTIC VIOLENCE, POVERTY, AND WELFARE}

The broad premise of the conservative reform movement has been the belief that welfare must be radically reformed because it does not actually reduce poverty, but merely breeds dependence and dissipates the "character" and integrity of its poor recipients. ${ }^{22}$ In particular, the conservative reformers have pointed to the profusion of non-working single mothers who appear to expect to support existing and future children on welfare, and the failure of fathers to either remain with the families they have spawned or to pay child support. Conservative reformers have also accused the poor of a host of personal ills including laziness, promiscuity, substance abuse, and general irresponsibility in the bearing of multiple children who the family cannot independently support. In keeping with these moral judgments of welfare recipients, the conservative reformers have demanded and achieved an end to the federal entitlement to public assistance, time limitations on the availability of welfare, requirements of ongoing employment, and various forms of penalties for women who depend upon welfare (PRA 42 USC $\S \S$ 602(a), 607, 608).

However, recognition of the impact of domestic violence on the plight and behaviors of many single mothers on welfare challenges many of the conservative reformers' most fundamental assumptions and policy prescriptions. Without purporting to offer an exhaustive critique of the latest federal and state welfare reforms, this section discusses the implications of the role of domestic violence in welfare receipt for three key themes of conservative welfare reform present in both the PRA and many state policies. ${ }^{23}$ First, the push for tightened paternity and child support and more marriage requirements stems from the assumption that poverty is a result of singleparent female-headed families and that the return of men to the family will end the need for welfare. Second, the increasingly stringent work requirements and time limitations on receipt of welfare are driven by the assumption that welfare recipients don't work because they prefer to receive welfare. Third, "child exclusion" or "family cap" policies are based on the assumption that women on welfare bear additional children because welfare makes it financially viable or even desirable. Underlying all of these assumptions and policies is the fundamental misconception that welfare recipients' behaviors are driven by irresponsible choices and can be controlled by incentives and disincentives embedded in welfare policy. The reality of domestic violence poses a new ${ }^{24}$ challenge to this misconception and a powerful obstacle to broad implementation of such policies.

First, perhaps the most fundamental tenet of conservative welfare reform is the belief that single-parent families are per se dysfunctional and that fathers must be returned to the family if families are ever to regain economic self-sufficiency (Blankenhorn 1995). Thus, the first two legislative findings of the PRA extol marriage (PRA $\S 101(1),(2)$ ), and both the findings 
allu the pullites of the stalute place a prionty on child support entorcement and paternity determinations (PRA $\S 101(4)$; 42 USC $\$ \S 608(\mathrm{a})(2), 609(\mathrm{a})$ ). Under the PRA, while marriage is more a symbolic goal than a concrete condition for receipt of benefits (PRA $\S 101(10)$ ), cooperation with establishment of paternity and collection of child support is specifically required for all who seek benefits. However, this emphasis on involving fathers, many of whom are abusive, in the family ignores the risks such men may pose to both mothers and children. Many survivors are (rightfully) terrified of bringing the abuser back into their life in any manner, especially as a defendant in a lawsuit. Studies have shown that a substantial proportion of divorcing women are afraid for their safety during negotiations for child support, custody, or property in the course of a divorce (Kurz 1995: 13537). Legal action against an abuser, particularly for child support, may well provoke retaliatory abuse. For instance, in one case handled by my clinic, the client was forced to take her children, leave the city, and go into hiding after her abuser, in response to the initiation of a child support action against him, went to members of her family and friends, demanding to know where she was and announcing he would kill her. (He had not had a similar reaction to her previous filings for protection orders.) Although exceptions to paternity identification and cooperation with child support litigation are allowed for "good cause" under the PRA (42 USC $\$$ 608(a)(2)) as they were under prior law, state welfare agencies have been notoriously reluctant to allow such exceptions and have rarely if ever applied them to battered women (Legal Services of Northern Virginia 1995: 17-18; Pollack 1996: 335-38).

A less-discussed companion to enhanced child support enforcement is the suggestion that more child visitation be provided in exchange for stricter child support enforcement (Mink 1994: 896-98; 42 USC $\$$ 669B). ${ }^{25}$ However, the reality and prevalence of domestic violence suggests that bringing many fathers back into children's lives may, far from increasing the economic viability of the family, produce the opposite result. Child visitation is one of the most frequent arenas for the continuing abuse of women and children. To the extent that these fathers are abusive to the mothers (and often to the children), ${ }^{26}$ their presence will jeopardize both the financial and physical security of the family, thus increasing poverty and dependence on welfare in those families. Because courts and legislatures still share a strong predisposition in favor of non-custodial fathers' rights to visit their children, limiting court-ordered visitation by batterers is already a challenge in battered women's litigation (Cahn \& Meier 1995: 351). A national welfare policy linking increased child support collection to increased visitation rights will make protection of women and children from abuse even more difficult. Even when further physical violence does not occur, the continuing presence of a perpetrator of abuse in the lives of abused women and their children is likely to exacerbate the psychological traumatization and any related symptoms experienced by both (Stark 1993: 
22-23; Herman 1992: 168-72). In short, "[p]aternal involvement is not what many mothers need" (Brush 1997: 250).

A second but more widespread theme in welfare reform has been the abandonment of the federal entitlement to welfare and institution of stringent new time limits for welfare receipt. Consistent with previous proposals, the new federal law now establishes a two-year one-time cap, and a five-year lifetime maximum (PRA $\S \S 602(a)(1)(A)(i i), 607,608(a)(7)$ ). Under the new law, welfare is essentially predicated (except for the $20 \%$ who may be exempted from the five-year lifetime limit) on the recipient participating in efforts toward employment $(\S 608(\mathrm{~b}))$. The implicit assumption is that women have until now stayed on welfare rather than working because they would rather not work.

Critiques of this assumption have already noted many reasons why employment is difficult for poor people to obtain and keep, from the cost and unavailability of child care or health insurance, to the profound limitations of a depressed unskilled labor market (DeParle 1996; Lynn 1993; Williams 1992; Mink 1994). For purposes of this essay, the point is simple but elemental: for many poor women, their inability to develop or maintain economic self-sufficiency is the result of violent victimization and intentional sabotage by abusers. As discussed in section II above, abusive men obstruct women's employment both directly and indirectly, by inflicting physical and psychological abuse and harassment which frequently results in job loss and inability to continue with education or training. This is precisely the result intended by many abusers. Invoking arbitrary time limits and lifetime maximums will do nothing to make poor battered women more able to obtain and hold jobs in the face of the violent opposition of men in their lives.

The third key policy reform is the "family cap" or "child exclusion." This policy denies additional welfare benefits to families in which an additional child was born while the mother was already receiving welfare. ${ }^{27}$ Although the PRA does not incorporate such a provision as a matter of federal policy, but leaves it to state discretion, Congress previously adopted the family cap in House of Representatives Bill 4 (1995), and it has in any event been adopted by a number of states (Pollack 1996: 331; Davis 1993). Such a policy clearly stems from the assumption, among others, that mothers on welfare who have another child are freely choosing to do so. Again, the reality and pervasiveness of domestic violence tells us that this vastly distorts the truth.

The reality is that a substantial number of children borne by women onwelfare are the product of violence, coercion, or "choice" which is compromised at best. Assuming conservatively that 15 to $30 \%$ of women on welfare are currently being physically abused, at least one-third (again a conservative estimate) of those women likely have been sexually abused as well. $^{28}$ In my clinical practice, clients frequently state that one or more of their children were the product of coerced, nonconsensual sexual 
intercourse. (Client disclosures of sexual abuse almost certainly underrefiect actuai incidence, given the strong resistance of most women to discussing sexual abuse, even with their lawyers (Bachman \& Saltzman 1995).) Moreover, even apart from instances of legally recognizable rape or sexual assault, many children are the product of sexual experiences that were coerced in other ways, for example, when birth control is rejected by an abusive partner. "Focus groups of survivors report that decisions about contraceptives are one of the many issues the abuser controls" (Guard 1997: 6-7, citations omitted). Finally, once a woman has been beaten by a man, it is highly unlikely that her decision to engage in sexual relations with him is an act of truly free will. The problem of coercion or lack of full free will is even more apparent in the recent discovery that a substantial proportion of teen pregnancies are fathered by adult men, and are often the result of statutory rape and sometimes incest (ibid.; Pollack 1996: 332 n. 14; PRA $\S$ 101(7)(B), (C)).

Again, coerced pregnancy is often intentional: Just as abusers need to prevent women from holding or obtaining jobs to keep them dependent on the abuser and not self-sufficient, many abusers want to make sure "their" women are "barefoot and pregnant" because that fits their view of women's proper place, keeps them dependent on the abuser, and ensures they are less able to act as free agents in the world. ${ }^{29}$ Men know that once they and the woman have children in common, they will always be connected to some degree, and they will have a permanent excuse for seeking contact with and control over the woman (Hart 1992: 33-34). Many women (including clients of mine) are morally opposed to abortion and do not see that as an option when they are forced to unintentionally conceive a child; some (also including former clients) fear violence from their abuser if they have an abortion. Moreover, in most states, poor women do not have Medicaid coverage for abortions (Harris v McRae 1980; Maher v Roe 1977); and, in any event, abortion is not an acceptable solution in the eyes of conservative welfare reformers (Friedman 1995: 659-61).

Rates of involuntary or coerced sexual intercourse and/or child-bearing are not captured in the under-reported rates of sexual assault or abuse measured by existing studies. We cannot know the exact extent to which women bear children without full and "free" choice, but we can know the rate of coerced sexual relations is higher than, say, the 20 to $35 \%$ of welfare recipients in Passaic County who have reported "sexual assault," "sexual abuse," or "rape." 30

Perhaps not surprisingly, however, in stated and federal policy making on this issue, the reality of widespread coerced pregnancy has been virtually ignored. ${ }^{31}$ Under the PRA, states are free to adopt family caps with or without rape exceptions defined as they see fit. Although House of Representatives Bill 4(1995) (a predecessor to the PRA), which contained a family cap provision, exempted children born as a result of rape, it left states free to define "rape," to establish proof requirements, to decide whether and 
how much to notify applicants about the exception, and what, if any, confidentiality or training requirements to impose on agency personnel (Pollack 1996: 332-35).

In any event, regardless of the contours of any particular rape exemption states may adopt, the mere establishment of such an "exemption" is predicated on the assumption that most women who bear children while on welfare are choosing voluntarily to do so. If, however, coerced or involuntary pregnancy is as common as voluntary and intentional pregnancy, or even if it is common for one-third of the population, it is a fairly prevalent norm, and the entire premise of child exclusion must be reconsidered. Using welfare policy to penalize women who have been coerced into childbearing merely punishes such women for something they could not control.

In sum, all of the incentives and disincentives attached to conditioned welfare grants will be irrelevant as long as women's lives are not their own, because they are either controlled and coerced by a violent person or are suffering the after-effects of trauma inflicted by a violent partner. "Based on our current knowledge ... no programs or interventions designed for very low-income mothers and children - whether they be welfare-to-work policies, health policies, or educational programs for children - can be fully effective if they do not take into account the reality that the violence is omnipresent in their lives" (Browne \& Bassuk 1997: 276). Furthermore, the moral premises of welfare reform, i.e., the blanket castigation of women receiving welfare for their "dysfunctional" or "immoral" behaviors, cannot be sustained in light of the role of domestic violence in poor women's lives. Behaviors such as dropping out of job programs, substance abuse, or repeated childbearing on welfare, are occurring in many cases in the aftermath or face of violence - violence which is beyond the control of the victim, and is often intended to achieve exactly the result of preventing the woman's selfsufficiency.

It is worth noting the positive side of this coin: to the extent that conservative reformers seek to reduce childbearing by women on welfare, reducing domestic violence should have precisely that effect. As is discussed in section VI below, the "Family Violence Option" (FVO) incorporated into the PRA $(\S 608(a)(7))$, which allows states to identify and refer domestic violence victims to counseling and legal services, as well as to temporarily waive program requirements where necessary, may thus better meet even the goals of welfare reform than the more common and punitive policies such as a family cap. However, concerted advocacy continues to be necessary to minimize harm to battered women from the new welfare laws. More fundamentally, the battle must continue on a philosophical plane, to reframe perspectives on women and welfare, and to enable poor women to reclaim at least some of the moral high ground which the conservative reformers have seized in attacking the moral integrity of single mothers on welfare. The next section addresses these ideological perspectives as seen in both the debate 
over welfare reform and in the history of the gap between the anti-poverty and battered women's movements.

\section{IDEOLOGICAL IMPLICATIONS OF THE LINK BETWEEN DOMESTIC VIOLENCE AND POVERTY}

\section{A. CHARACTER REFORM VS. SOCIAL CHANGE IN THE WELFARE REFORM DEBATE}

With President Bill Clinton's signing of the Personal Responsibility and Work Opportunity Reconciliation Act of 1996, an era ended. The beliefs that the nation is obligated to assist its poorest citizens and that the poor are poor through no fault of their own, hard fought by many anti-poverty activists through the 1960s and 1970s (Davis 1993), have been abandoned. In their place is the now dominant philosophy, held even by some selfdescribed liberals, that poor people could support themselves if they tried hard enough (Vobejda 1996: A1). While compassionate people may disagree about the merits and comparative advantages and disadvantages of welfare as a system, and few would defend it as a positive experience for its recipients, the push to end welfare was not initiated as a compassionate attempt to alleviate poverty, but was, rather, inspired by anger at welfare recipients and their perceived immoral "rip-off" of the state. In short, welfare reform has unquestionably repudiated the principles of progressive poverty activism. What has been striking about this "counter-revolution," however, has been the relative silence of the political Left, and the almost complete absence of any effective or powerful counters to the conservative attack on welfare and the poor (Tomaskey 1996: 99). Where has the progressive anti-poverty movement been?

In general, throughout this debate, progressive poverty activists and thinkers have refused to respond to the conservative attacks on the character of the poor and the philosophical or moral debate at the heart of the proposed radical retrenchments of welfare. Instead they have dismissed the conservatives' moral critique of single motherhood and proposed remedies as merely a means of scapegoating the poor, stating, for instance, " $[t]$ heir statements are part of a disturbing effort to divert attention from the structural problems of our society and to focus instead on the so-called deviance of the poor" (Williams 1992: 719, 741-46). Poverty advocates have clung instead to a traditional understanding of poverty as a function of socioeconomic forces over which the poor have no control, such as the decrease in demand for and wages of low-skilled workers, racial and gender discrimination in employment, inadequate education, and national and international economic trends toward deregulation and non-protection of workers' rights (Lynn 1993: 86-88; Williams 1992: 742-45; Mink 1994: 88889). To the extent that they acknowledge that some behaviors of poor people are "dysfunctional," progressive analysts have argued that poverty 
itself is the cause of those behavioral dysfunctions (Williams 1992: 719). Thus they have argued that poverty itself is the "single most important predictor" of "deviant family values," such as substance abuse and single parent families (Handler 1994: 862) ${ }^{32}$ At root, these thinkers have criticized the reformers' obsession with "family values" and individual character of the poor as a reflection of class selfishness, gender, and racial bias, and an unwillingness to help anyone different from themselves (Williams 1992: 741-46; Hartman \& Spalter-Roth 1994: 907). Among progressive poverty analysts, "character" and gender roles are simply perceived as invalid considerations in discussions of poverty (Margulies 1996: 1082). However, because the moral and philosophical discussion of desert and merit are at the core of the movement to remake welfare, anti-poverty advocates, in refusing to engage in the moral discussion, have essentially abdicated the debate (Tomaskey 1996: 112-14).

Explicitly feminist critics of the conservative welfare reformers' goals and assumptions have been more willing to engage in the discussion of morality and gender roles. In particular, feminists have countered reformers' claim that single-mother families are inherently bad or dysfunctional, have argued that the existing "male model" of work makes many poor mothers' steady employment virtually impossible, and have critiqued the conservatives' refusal to acknowledge the particular needs of employed women who are primary caretakers for children (Fineman 1991: 282-89; White 1994: 84649; Mink 1994: 883-99; Hartman \& Spalter-Roth 1994: 907). Thus, these critics have acknowledged a moral component to the welfare reform debate, and have defended the "morality" of poor women's choices, as against their widespread denigration by much of society.

However, surprisingly, prior to the national focus on the intersection of domestic violence and welfare triggered by the 1995 NOW LDEF Conference, feminists engaged in the welfare debate generally did not defend the morality of poor women's "choices" by pointing to the coercion and abuse so many women suffer at the hands of men. In the majority of the explicitly feminist scholarly analyses of welfare reform, domestic violence has not been raised, despite its being a major contributor to the painful plight of single mothers on welfare. For instance, Martha Fineman (1994: 4-6, 1991: 283) powerfully critiques the negative view of single mothers held by both conservative and "liberal" thinkers, and envisions a new concept of "core family" as mother and child, but in these discussions she does not address the possibility that many mothers are single, not because they wish to be, but because of "dysfunctional" or abusive behavior on the part of their partners. Similarly, Lucy Williams, in an earlier challenge to conservatives' attempts to change the choices and behaviors of poor women, argued that poor women are no different from those not receiving AFDC, in that they "want to be parents and to share their lives with a child ... [There are many reasons why AFDC mothers become pregnant . . . including] occurrences of unplanned pregnancies (whether due to a lack of information, money or 
forethought)" (Williams 1992: 738). While she powerfully defends women's right to make this choice, she does not acknowledge the possibility that - as discussed earlier - a significant number of women (both poor and not poor) bear children they did not seek as a result of males' sexual abuse. Similarly, Gwendolyn Mink's scathing feminist critique of the conservative reformers' emphasis on returning men to poor families makes no mention of domestic violence (Mink 1994: 896-98).

The absence of any discussion of domestic violence in these feminists' analyses of the welfare issue is particularly notable in light of the fact that some of them are leading scholars in the domestic violence field (see, e.g., Fineman \& Mykitiuk 1994). The fact that their expertise extends to domestic violence has made the absence of it in their welfare/poverty discussions all the more striking. ${ }^{33}$

Nor can this absence be wholly explained by the fact that domestic violence was not known to be as widespread among the welfare population as it now is, or that empirical data on the relationship between domestic violence and poverty were not available. These data have appeared now only because researchers such as the Taylor Institute sought them out specifically in order to investigate their suspicion that domestic violence significantly affects poverty and welfare dependency. At the risk of overgeneralization, I believe that most battered women's activists who have worked with poor women knew or would have recognized, if asked, the significant correlation between domestic violence, poverty and welfare dependency. ${ }^{34}$ Had the empirical inquiry been launched in 1990, the data would almost certainly have been equally available and consistent with the statistics being gathered today. However, until very recently, something kept even most feminist scholars or researchers from either generating the data or explicitly addressing this link. ${ }^{35}$ The lack of acknowledgement of this pre-eminent "feminist" issue in otherwise broad feminist responses to the conservative welfare reformers, as well as those of mainstream poverty progressives, suggests that there have been deep historical and philosophical reasons for the separation of the issues of domestic violence and poverty.

\section{B. THE HISTORIC SEPARATION OF THE POVERTY AND DOMESTIC VIOLENCE MOVEMENTS}

\section{In Practice}

The fact that domestic violence has not been a part of either progressive or feminist discussions of poverty/welfare reform is due in part to the historical disconnection between practitioners in the poverty and battered women's movements. For instance, Peter Margulies (1996: 1071-72, 1078-79; see also Miller 1995: 117) argues that family law and domestic violence work have been marginalized in legal service programs, pointing primarily to a 
traditional sexism which undervalues "women's" issues, and a preference for "public" over "private" litigation. In contrast, while many battered women's activists have worked with poor people in legal services, state coalitions and shelters, law school clinics, and other pro bono or non-profit programs, with the exception of a handful of legal service lawyers, such advocates have typically specialized in domestic violence, not offering other traditional "poverty" advocacy, for example, welfare, housing, etc. ${ }^{36}$ Indeed, many domestic violence activists have traditionally avoided welfare advocacy in particular, because the welfare bureaucracy was perceived as deeply disempowering and stigmatizing for battered women. Such bureaucratic hostility and pathologization of battered women has too often led to battered women being penalized for batterers' abuse, deprived of custody and prosecuted for "failure to protect" the children from the batterer (Enos 1996; Miccio 1995). ${ }^{37}$

Separation of the "disciplines" or topics of domestic violence and poverty has also been apparent at the micro-cosmic level of clinical teaching, at least in my own program, and to some degree in others. Until quite recently, although I, like many other clinical professors, work primarily with poor clients, ${ }^{38}$ I focused in both my teaching and my writing on helping students and readers come to grips with the gender issues surrounding domestic violence more than with the role of poverty in my clients' lives. My feeling has been that if students (and police, prosecutors and court personnel) do not understand that domestic violence is serious, intentional, not mutual, and not the victim's fault, victims cannot receive minimally competent professional assistance. With a few exceptions (Bryant \& Arias 1992; Barry 1994), this is fairly typical of domestic violence clinical programs around the country (Merryman 1993). However, over the years, as the gender issues have become less alien and more widely understood by students (as by society), I have found students struggling harder with issues relating to clients' socioeconomic status and race. For instance, while battered women's ambivalence about legal action against their abusers is now fairly widely assumed and at least to a limited degree understood, some of us (who are white) have been challenged more than once to understand clients' ambivalence about" "sending another black man to jail ... especially one with no previous criminal record." Similarly, while clients' failures to come to appointments or respond to phone calls are sometimes due to personal ambivalence about proceeding, students have struggled to understand (and believe) clients' statements that they simply could not afford the bus fare to the clinic or could not find child care. Increasingly I find that understanding these racial and economic dimensions of our clients' lives is critical to our ability to maintain a constructive and respectful relationship with them, as is our understanding of the complexity of domestic violence. Yet, in my experience, teaching both types of issues can invoke resistance from students who feel that poverty is "not what this [domestic violence] clinic is supposed to be about." 
Of course it is also true that many battered women's activists, and several state coalitions, have worked simultaneously as anti-poverty activists, for example, working with legal services offices on poverty and domestic violence cases, lobbying welfare reform proposals which harm battered women and other poor people, and banding together with legal service and other non-profit entities facing devastating cuts and burdens from increasingly hostile state and federal legislatures (Trubek 1995: 8-9; Davies 1996; Zorza 1996a). Indeed, some of the earliest and most important accomplishments of the battered women's movement were achieved by legal services lawyers. For instance, the former National Center on Women and Family Law ("NCOWFL"), sadly closed by congressional cutbacks in 1996, was a Legal Services Corporation "backup center" for legal service attorneys around the country. The NCOWFL was one of the first national resource centers on domestic violence which specialized in this issue when very few lawyers or policy makers were aware of it. The first watershed litigation against a police department was initiated by attorneys at MFY Legal Services, Inc., in New York City and other public interest lawyers (Woods 1978: 7). More recently, some legal services attorneys have done groundbreaking work in articulating a broader, safety-oriented and "womandefined" approach to representing battered women (one which is especially applicable to poor women); others have led some of the challenges to welfare reform (Davies 1994, forthcoming 1997; Pollack 1996, Pollack \& Davis 1997). ${ }^{39}$

However, in general, collaboration between domestic violence and poverty activists has been fairly local and isolated as a political matter. Even where legal service lawyers work on domestic violence issues, they have tended to do so in relative isolation from the mainstream of legal service offices. Institutionally, and more importantly, philosophically, integrating the "causes" of domestic violence and of fighting poverty has remained problematic. As the Deputy Director of Idaho Legal Services found in a recent survey of female attorneys in legal services:

Many women strongly value their litigation and advocacy efforts on behalf of battered women and wish more of their program's resources were committed to family law. "If I leave this program," one wrote, "it will be because of a lack of commitment of resources to family law and domestic violence, resistance to seeing these areas as 'poverty issues' and a general failure to integrate awareness of abuse and feminization of poverty into the practice as a whole" (Miller 1995: 1171).

As already noted, this difficulty has also been reflected in both the poverty and battered women's movement's theoretical work: While some domestic violence scholars have "demonstrated sensitivity to issues of poverty . . . an integration of domestic violence and poverty theory has proved elusive" (Margulies 1996: 1084-85). 


\section{The Clash of Ideologies between the Battered Women's and} Anti-Poverty Movements

At the heart of the disconnection between progressive discussions of poverty and feminist discussions of domestic violence is a fundamental clash of ideologies and philosophies between the domestic violence and anti-poverty movements, one which parallels the clash between the ideologies of conservative reformers and poverty activists in the welfare reform debate. On the poverty side, the feminists' emphasis on the values and attitudes which lead to abuse and the need for moral education of perpetrators in order to change their beliefs and behavior, is anathema to anti-poverty activists who preach the structural and socioeconomic causes of the ills of the poor and who see any talk of moral or dysfunctional behavior of the poor as a form of blaming the victim. On the domestic violence side, battered women's activists have strenuously avoided discussing battering as a problem related to poverty in order to avoid its marginalization and to further the understanding that domestic violence is a reflection of fairly universal norms of a sexist society. The moral righteousness of the battered women's movement, which casts battering men as guilty perpetrators and battered women as innocent victims, sits uneasily with the poverty activists who see talk of moral judgment as a form of blaming the victim; at the same time, poverty progressives' emphasis on poverty as the cause of violent behavior in the family seems on the surface to be incompatible with the battered women's movement's emphasis on unjust gender oppression as the source and ultimate cause of domestic violence. At first glance, the perspectives are quite incompatible. This potential clash has caused even feminist poverty analysts to separate out the domestic violence issue and pigeonhole it as a "feminist" - but not particularly a "poverty" - issue. ${ }^{40}$

(a) The Battered Women's Movement's Historic Avoidance of the Poverty Issue. In the early days of the modern battered women's movement in the 1970 s, the concept of domestic violence was barely recognized by the dominant society. To the extent that domestic violence was acknowledged, it was often accompanied by the assumption that abusing women was something that poor men did because they were culturally or naturally more violent (Pleck 1987: 51; Gordon 1988: 3, 8). Indeed, historically, in antebellum America, attention to family violence was associated with male drunkenness common among the "working class" (Pleck 1987: 51). Similarly, child abuse historically was documented and provoked intervention largely in poor families, because they were "more likely to be "caught"" (Gordon 1988: 8). Thus, as the battered women's movement gathered definition, it was clear that in order for the issue to be adequately grasped by the larger society, it would be critical to bring the issue "home" to the dominant sectors of society, and to convince them that battering was not "merely" a problem of the poor, but stems from patriarchal cultural norms which cut across ail classes. This was not merely a political tactic; it was also 
an expression of the fundamental creed of the battered women's movement that battering is culturally condoned, taught and inherited, and that only a fundamental social and cultural transformation in views of gender roles would put an end to it (Dobash \& Dobash 1979). Many active in the movement also felt that a discussion of domestic violence and poverty in the same breath would only lead to furthering racist and classist prejudices rather than greater understanding of the problem (Dobash \& Dobash 1992: 52-54). Hence, the battered women's movement has long claimed that domestic violence "occurs among all races and socio-economic groups" (National Woman Abuse Prevention Project, n.d.; Gelles, Lackner \& Wolfner 1994: 4).

It should be noted that progressives' concern that state intervention into the family on behalf of battered women would, if not controlled, merely target the poor and reflect race and class bias is not new or unique to the issue of adult domestic violence. Attempts in the early 1970s to address child abuse were also undercut in part because of liberal concern that child protection interventions were class-based and "separated mainly poor and minority children from their families" (Pleck 1987: 179, citing Wald 1975: 985-1040, 1976: 673-706). Linda Gordon's (1988: 3, 8) examination of child protection records in Boston from 1880 to 1960 lends unfortunate truth to this claim, in at least one community in the past. Thus, the historical division of progressive civil rights activists between child protectors and defenders of the poor was an almost perfect foreshadowing of the doubleedged dilemma currently confronted by the anti-poverty and battered women's movements.

Nonetheless, perhaps ironically, critiques of the intentionally "universalist" thrust of the battered women's movement have challenged it as "essentialism" or "privilege" (Crenshaw 1991: 1242-43, 1258-60). Kim Crenshaw (ibid.) notes that the "domestic violence lobby's" emphasis on the "universality" of domestic violence is intended to focus society's attention on white middle-class victims, precisely because poor people of color are less valued by dominant society. Her perception of this political choice as suspect is supported in part by the tainted history of both the women's movement's and the battered women's movement's treatment of women of color and their concerns (Ruttenberg 1994: 176; Crenshaw 1991: 1264-65). ${ }^{41}$ There is also little doubt that the support of privileged white males and their constituents for battering issues may be predicated in part on a racist devaluation of poor people of color. However, the fact remains that had the new paradigm of battering been explicitly connected to poverty before battering was broadly understood and accepted as a serious and widespread social problem, it would have merely contributed to the demonization of poor people, and would not have advanced societal understanding of battering or of poor people of color. Thus, one member of the federal government involved in developing federal policy on domestic violence in the late 1970s later stated "there was a federal response because the problem 
cuts across class and race. If domestic violence affected only poor women, it would have been dismissed" (Pleck 1987: 193-94).

Between the devil's choice of painting the issue of battering as a class and race-based problem, and the "deep blue sea" of portraying it as cutting across class and race, then, the universalist emphasis was seen by many activists as the most responsible political choice. This strategy was intended both to avoid dominant society's inclination to dismiss domestic violence as "somebody else's problem" and to minimize the possibility of poor people or people of color being tarred with the domestic violence brush. ${ }^{42}$

Nonetheless, the strategy has not been without cost. Crenshaw (1991: $1262-65)$ rightly notes that the battered women's movement has been of limited effectiveness in poor communities and communities of color, particularly non-English-speaking populations. At this point, not only the welfare studies discussed in section II, but both new and existing data on domestic violence and income discussed in section V(B) below, leave no doubt that domestic violence occurs at a greater rate in low-income communities. There has been a growing recognition of late that "[w] hatever we've done to prevent domestic violence has been more effective for white [middle and upper class] women, and we have to figure out how to make it apply to poor women in poor areas" (Belluck 1997; see also Richie 1996: 20-21). To the extent that some poor communities consist predominantly of people of color, the fact that battered women's activists have been predominantly white, relatively privileged and have not always shared an equal commitment to race issues, has contributed to the resistance of these communities to the movement's message (see generally Richie 1996). In my view, this disconnection is also due in part to the battered women's movement's narrow focus on the psychological and political dimensions of domestic violence, which has tended to exclude concerns such as economics, that, not surprisingly, are often central to poor people.

The limitations of a non-racially-conscious approach to domestic violence are exemplified by two cases which my clinic handled in the spring of 1996. In the first, the client came to us after the father of her baby had violated her civil protection order in a series of severe attacks, some of which included holding their infant and two knives in his hands and threatening to drop the baby and/or stab the client. When she first met with us, she was determined to see him sent to jail, and expressed her fear that he might not be. Subsequently, in a conversation prior to the trial, she expressed profound ambivalence about a jail sentence, in large part because she feared the abuser would orchestrate retaliation by neighborhood drug dealers. When I mentioned that most women in her situation are ambivalent and afraid of going forward with a prosecution but that it has been beneficial in most cases, and that none of my clients had in fact been retaliated against, she challenged me: "white women or black women?" She seemed surprised when I informed her that almost all of my clients have been black. After she decided not to withdraw the jail request, and after an intense but successful 
trial, she became distraught when her abuser was sentenced to two months in prison. She then informed the students that she could not bear being responsible for ruining his "clean record," and sending "another black man to jail." Moreover, she felt strongly that he was a "good man," who held down a regular job, was working to advance himself, and was an "elegant" person who did not belong in jail. Ultimately she wrote a letter to the judge requesting a reduction of his sentence, which was denied. In addition, without informing the clinic, she went to court and had the civil protection order withdrawn.

While similar patterns of ambivalence about taking legal action against an abuser are common among women of all races, and while this client may have had some other psychological issues that were not solely race-based, I found this case particularly poignant on that score. There was little I could say to her that could reduce the harm she felt she would have to inflict upon herself and her community, as well as the respondent, by sending him to jail. And because I am white, my expression of my belief that she deserved to be treated with respect and without violence, and that he deserved the penalties that flowed from his use of violence, could not have the credibility it would have had coming out of the mouth of another woman of color. She could not really trust my judgment because she could not trust that I was giving appropriate (or any) weight to the racial cost of her receiving "justice."

Another case the same semester complemented the first in almost astonishing ways. This client was not native-born. Her middle-class AfricanAmerican husband had beaten her over a period of years. When she finally took him to court, he challenged her by saying "why do you want to take me to the white man's system?" She responded that she had attempted for approximately two years to obtain "justice" by mediating the problem with the community "elders," and that they had not given her justice. She hoped that she would receive more justice in court.

While her case was purely civil, and she did not want to pursue any criminal remedies, this client appeared remarkably clearheaded about her loyalties to both her community and herself. She had spent years seeking assistance from the community "elders" because she was loyal to her race and community. However, when that community let her down, she chose not to allow it to negate her rights as a human being; she turned to the civil legal system, which did ultimately provide her with better protection and vindication of her rights.

Both of these cases, despite their opposite outcomes, demonstrate the crucial relevance of race to the representation of minority battered women. That these anecdotes are not unique is supported by some pioneering community research initiated by Gail Garfield, co-director and co-founder of the institute on Violence against African-American Women. In a series of focus groups organized to explore the experiences and views of women of color regarding abuse, the institute found that women of color (from many different walks of life) do indeed feel very torn between protecting them- 
selves from men's abuse and protecting the men and the larger community from derogation by the white community. Women in the focus groups repeatedly mentioned the double bind they face in "betraying" their community if they report intimate abuse to the authorities (Richie 1996).

In short, stock answers about women's "ambivalence" or fear do not respond to some of the powerful conflicting motivations with which black battered women must contend (Richie 1985). Some black clients have difficulty trusting white lawyers; many white lawyers (and students) have difficulty understanding the particular conflicts of black battered women. Without attempting a full discussion of this issue - which is deserving of its own article - it should be apparent that the battered women's movement needs to work, on both an institutional and personal level, to bridge this gap. The movement's new focus on the intersection of battering, poverty and welfare is a valuable first step in this direction.

(b) The Incompatibility of the Battered Women's Movement's Ideology with the Premises of the Anti-Poverty Movement. While the battered women's movement has, in the context of welfare reform, begun to address the link between poverty and domestic violence, the anti-poverty movement has yet to do so. This may be in part because the movement itself is currently so weak and lacks a powerful voice on behalf of poor people (Tomaskey 1996: 96-117). However, in greater part it is because the integration of the issue of domestic violence into poverty activism poses a far deeper challenge to the nature and ideology of poverty activism than the integration of poverty concerns poses to domestic violence activism. This challenge is not merely historical or political but a philosophical and current challenge to fundamental tenets of anti-poverty work. The following describes the inherent conflict between the ideologies of the battered women's movement and the anti-poverty movement. In section IV I discuss how and why synthesis of the two ideological perspectives is both possible and potentially beneficial to
each movement.

At heart, the battered women's movement has long been characterized by the passionate conviction that an adequate response to domestic violence requires increased criminalization of domestic violence, holding batterers "accountable" by sending them a clear message of criminal responsibility, and imposing stronger sanctions. Domestic violence scholars and advocates have thus frequently argued that mandatory arrest and aggressive prosecution of batterers is necessary to challenge men's notions of their "right" to control and beat their women (Zorza 1992: 53-64; Hart 1992: 69-70; Dobash \& Dobash 1979: 138; Meier 1993: 1304). The moral judgment implicit in criminal sanctions has been seen as critical to stopping domestic violence because domestic violence is more than merely the unpredictable occurrence of violence between intimates. At core, battering is a pattern of intentional coercive control enforced by abusers through both violent and non-violent means, premised on the abuser's moralistic conviction that 
women are subordinate to and should obey men (Stark 1995: 975-76). Moreover, individuai men's beliefs that physical violence against their female partners is appropriate to enforce their authority, must be understood in context of the history of patriarchal norms throughout western society which both explicitly and implicitly conditioned both men and women to believe in men's rights to dominate and control women (Dobash \& Dobash 1979: 31-74; Schechter 1982).

Because battering is really a value or belief system as much as or more than a behavior pattern, challenging the moral validity of the beliefs is as important as stopping the physical behaviors. Batterers often devote enormous energy to proving they are right and the victim is wrong, that they are good and virtuous, and their victim is bad and evil. The "culture of battering" is a highly moralistic one, often defined by elaborate "rules" laid down, both explicitly and implicitly, by the abuser (Fischer, Vidmar \& Ellis 1993: 2126-29). The abuser typically believes he is right; that his abusiveness is justified, even necessitated, by his victim's "insubordinate" or other rulebreaking behavior.

Thus, as most batterers' counselors know, the most effective batterers' counseling programs have been those which challenge the men's sexist beliefs and teach them new attitudes toward women. ${ }^{43}$ However, battering does not change until the offending individual accepts personal responsibility for wrongdoing (Adams 1988: 196; Paymar 1993). Such a change in an individual's moral framework is unlikely in the absence of meaningful criminal sanctions, which back up the demand that abusers change with the threat of pain and the label of "wrongdoer" (Adams 1988). Criminal law is our society's way of explicitly labeling behavior both wrong and immoral and of re-framing the moral "culture" of the parties' relationship. Without the moral message implicit in a criminal justice response, men's patriarchal assertion of their rights to control women cannot be expected to disappear. ${ }^{44}$ For these reasons, most battered women's advocates believe that criminal sanctions, which provide new "moral education" for both batterers and society, are necessary to counter both the moral righteousness of batterers and the centuries of social and cultural conditioning which have inculcated those values. ${ }^{45}$

However, it is this very moral message which is anathema to those with strong anti-poverty convictions. The fundamental ideology of the progressive anti-poverty movement has been a belief that the poor are, as a class, victims of an unjust social, economic, and political order. Such "poverty progressives" are fueled by their belief that both the causes and cures for poverty are social, economic, and political, but not behavioral. This philosophy has evolved out of poverty activists' longstanding conviction that poverty is inherent in our socioeconomic system and cannot be blamed upon poor people, as well as their history of battling against "morals policing" of the poor by the welfare bureaucracy (Margulies 1996: 1082; Gordon 1994: 298-99). Some have suggested that it also reflects a lack 
of appreciation for gender issues and a desire to avoid "dirtying their hands" with messy issues of family conflict and gender roles (Margulies 1996: 1078-80; Davies 1996). ${ }^{46}$ Within this ideological framework of antipoverty activism, public litigation has been privileged over private, and the core battles have been defined as those on behalf of poor individuals against powerful institutional oppressors - for example, the state, the landlord, or the bill collector - entities or individuals who further an oppressive socioeconomic order. In contrast to the battle for social and economic "justice" on behalf of the poor against more powerful institutions, litigation by a wife against a husband is litigation by one poor person against another poor person, a family member. Certainly, in pitting the poor against each other, it might be said that there is "no net gain" for the poor community. ${ }^{47}$

However, the problem of incorporating domestic violence into poverty work is more than just a matter of fighting the "wrong battles," Indeed, if that were the only problem, family law would be equally distasteful to legal services programs, as custody and divorce cases also pit the poor "against each other." In fact, family law has been more or less a staple of most legal service programs (Woods 1982: 28), if a less respected one, but domestic violence has been a relatively unusual component of most offices' caseloads (Margulies 1996: 1077-78). It is my belief that this is true not only because of sexism or disinterest, but because the "moral righteousness" of domestic violence work potentially demonizes the very individuals, poor men, who in poverty lawyers' eyes are the innocent victims of a larger social injustice (Margulies 1996: 1082). Indeed, in this sense the philosophy of the battered women's movement could be felt to echo the conservative welfare reformers in accusing a segment of the poor of immorality and bad character.

Not surprisingly, the preferred perspective of advocates for the poor is to frame battering in poor communities as another product of poverty; a tragic expression of poor, often African-American men's rage and frustration at racism and their own oppression by white, dominant society. This view of battering within the poor black family is portrayed in the movie Straight Out of Brooklyn (1991). In this story, the father brutally beats his wife repeatedly. However, this violence is portrayed as flowing from the man's rage at his own treatment by the larger society and hopelessness about the future, as well as the surrounding violence in the community. The abusive episodes contain no epithets, no attempts to dominate and control the wife, and no degradation of her. They appear to simply be outbreaks of violence taken out on her because she is available (and perhaps because she is loyal).

The problems with this paradigm of domestic violence among the poor are twofold: It exacerbates social denial about battering, and it feeds into the view that domestic violence is "caused" by poverty. The poverty advocate's paradigm provokes sympathy for the batterer and invites us to feel sorry for him because he is victimized on a larger level ${ }^{48}$ To those of us who do believe that poverty and racism are terrible social injustices which have profoundly harmed many people, there is a kernel of truth in this portrayal. 
However, invoking that sympathy or concern in the context of domestic abuse unfortunately plays directiy into abusers' denials of responsibility, supporting the trap that battering typically lays for its victims: "I beat you because $I$ am hurting, $I$ am the victim, and you have failed to treat me right." It is precisely this dynamic which has kept many women "loyal" and victimized, and has encouraged both society's and their belief that the women's failures, inadequacies or provocations are responsible for the battering.

Perhaps worse, the "poverty paradigm" of battering lacks recognition of the dynamic of the intentional exercise of power and control that fuels battering. This view essentially explains battering as not goal-oriented or gender-based but merely an untargeted explosion of the pain and rage caused by poverty and racism. Recognition that battering is intentional and goal-oriented, aimed at keeping its victim under the perpetrator's control and possession, is the most profound and radical element of the battered women's movement, for it demonstrates that battering is simply the logical extension of the sexist belief that men have the right to dominate women. However, if battering among the poor were portrayed and understood as being a brutal form of sexism, it would be far harder for those who work with poor men to feel sympathy (unless they were too profoundly sexist) for their clients. Thus, treating battering as an outgrowth of poverty rather than a behavior motivated by malevolence and sexism, allows anti-poverty advocates to remain morally engaged with their clients and cause. Sadly, it also contributes to the deep denial about the nature of battering which still seems to exist in poor communities of color, ${ }^{49}$ and sacrifices women and children in the name of "enlightened" dedication to the poor.

\section{A CALL FOR A SYNTHESIS OF THE SOCIAL CHANGE AND CHARACTER REFORM PERSPECTIVES OF THE ANTI-POVERTY AND BATTERED WOMEN'S MOVEMENTS}

\section{A. ANTI-POVERTY ADVOCACY}

Without discarding the basic premise that poverty is not poor people's fault, but is caused by socioeconomic forces, this essay argues that until the poverty progressives incorporate into their thinking and activism the knowledge that oppression of the poor is committed not only by the state or powerful members of society, but also by the equally poor partners of many women, the poverty of women and children will continue. This means that defenders of the poor must engage in the debate concerning character and behavior as a source of poverty and "behavior modification" as a means of welfare reform. The conservative welfare reform movement has brought family conduct and moral considerations to center stage in the poverty law drama. The refusal of poverty activists and thinkers to engage on these 
issues has not made them go away; on the contrary, the conservatives' "moral dialogue" has dramatically captured the public discussion. Moreover, recognition of the reality of domestic violence and its connection to poverty requires recognition that familial dysfunction and destructive "values" are major contributors to the poverty of a substantial population. Insofar as stopping domestic violence requires teaching (for example, through batterers' counseling) or forcing (for example, through criminal sanctions) a change in the behavior of batterers, by sending them the clear message that battering is unacceptable conduct, the link between domestic violence and poverty means that to some extent remedying poverty does entail changing some dysfunctional behaviors of the poor.

The core challenge for anti-poverty advocates in coming to terms with this issue is to incorporate feminists' understanding of battering as intentional sexist oppression of women by men into the larger view of poverty as a profound form of socio-economic oppression for which poor individuals are not responsible. The notion that the poor are "not responsible" for their own poverty must be tempered by recognition that battering of poor women by poor men actually does contribute, sometimes intentionally, to families' poverty. ${ }^{50}$ If we are concerned about poverty or about domestic violence, we must seek to hold poor men morally accountable as individuals for their abuse, while simultaneously recognizing their victimization by the larger social forces of poverty and/or racism. This perspective on battering and batterers does not change the reality that many poor batterers have suffered greatly as the victim of other people and larger social forces. It does, however, require poverty advocates to temper their view of the "victim" status of the poor with recognition of many poor men's perpetration of immoral destructive acts contributing, often intentionally, to others'

Movement in this direction could benefit the anti-poverty movement in several ways. Not only can emphasis on the interrelation between poverty and domestic violence inject a powerful moral weapon into the battle to protect the poor from the potentially brutal effects of welfare reform; it also has potential for revitalizing the anti-poverty movement itself. Over the past few decades, the anti-poverty movement has increasingly lost vigor and political and moral authority as the right-wing "war against the poor" has caught fire, legal services have been increasingly decimated by Congress, and work on behalf of the poor and against poverty has lost social respect and political status (Tomaskey 1996: 96-117). Sympathetic critiques abound: Professor Marc Feldman has accused the legal service community of stagnating and failing the poor because of an overly technical, "neutral" and procedural view of its mission, and a failure of "political engagement and contest" (1995: 1529). ${ }^{52}$ Others have critiqued legal services as lacking sufficient attention to the interactive effects of race and poverty (Powell 1993). Still others have posited that the growing political attacks on the merits of legal services for poor people should provoke self-assessment of 
whether and how we as poverty activists have failed to keep anti-poverty work powerful and alive (Lopez 1996). Whatever one's opinion of the reasons for the current weakness of the anti-poverty movement, ${ }^{53}$ its lack of ideological power and moral authority in our society is a disturbing fact. Perhaps partly because the old paradigms of victimization and innocence no longer work, more complex (and real) paradigms of the "virtue" of the poor are needed, and may arise as a result of engagement with the meaning of domestic violence among the poor. To the extent that poverty work itself has lost some of its moral power, incorporation of this issue into poverty advocacy also has the potential to re-inject passion and moral authority into the work. ${ }^{54}$

\section{B. DOMESTIC VIOLENCE ADVOCACY}

At the same time, the domestic violence movement has farther to go if it is to do justice to the implications of the connection between battering and poverty, which advocates have now begun to trumpet. ${ }^{55} \mathrm{~A}$ genuine acknowledgment of the interrelation between poverty and domestic violence must include recognition of not only how domestic violence exacerbates poverty, but of the many ways poverty exacerbates domestic violence, both as a practical and an emotional matter. At this point, such a synthesis is compelled not only by political circumstances, but by intellectual honesty: growing empirical evidence indicates that lower income is in fact correlated with higher rates of battering. In 1994, Richard Gelles and others, in a survey of social science studies of battering, noted that "[a]lthough there is, indeed, much empirical support for this conventional wisdom [that abuse cuts across all social classes], the data consistently indicate that although abusive behavior cuts a broad path, it does not do so evenly" (Gelles, Lackner \& Wolfner 1994: 4). Angela Browne and Shari Bassuk, two of the authors of the Worcester welfare study referred to earlier, have noted that "poverty constitutes a serious risk factor for both child abuse and violence by male partners" (Browne \& Bassuk 1997: 263). Specifically, they note that an earlier National Family Violence Survey (NFVS) found that "women married to men with lower occupational status or men who were unemployed were at greater risk of severe violence" (ibid.) (citations omitted). Now, new data from the Department of Justice's National Crime Victimization Survey also clearly reflect an increase in the rate of domestic violence as victims' income decreases. The survey found that victimization by an intimate occurs roughly four times more often when the victim's income is under $\$ 10,000$, than when it is $\$ 50,000$ or more (Bachman \& Saltzman 1995: 4). More specifically, the rates are 4.5 per thousand females with family income of $\$ 50,000$ or more; 5.4 per thousand at income levels of $\$ 30,000$ to $\$ 49,999$; 9.5 per thousand at incomes of $\$ 20,000$ to $\$ 29,999 ; 10.9$ per thousand at $\$ 15,000$ to $\$ 19,999 ; 13.3$ per thousand at $\$ 10,000$ to $\$ 14,999$; and 19.9 at $\$ 9,999$ or less (ibid.). Finally, 
the recently completed study by the New York City Department of Health on homicides in New York City, which was publicized for the finding that women are more likely to be killed by husbands and boyfriends than anyone else, also contained a less-noticed finding: that the murdered women were disproportionately from the poorest boroughs (the Bronx and Brooklyn), and black or Hispanic (Belluck 1997). While homicide rates may respond differently from assault rates to circumstances and associated disabilities of poverty, this finding is at least consistent with the crime victimization survey findings that rates of battering are correlated with income level.

What are we to make of the apparent fact that battering is more prevalent in lower income communities? The most innocuous interpretation is no different than the theory put forth in section II of this article: the data are perfectly consistent with the view that domestic abuse both makes women poor and keeps them poor (Davis, Coukos \& Lees 1996: 5). In other words, we need not read the data as identifying whether poverty is a cause or an effect of domestic violence. But do the data tell us something more about how poverty affects rates of domestic abuse? Surely, victims with less income have fewer resources to escape violence, by moving, changing jobs, etc., rendering them more vulnerable to continuing and higher rates of abuse (Crenshaw 1995). And surely this fact would be reflected in greater rates of domestic violence at lower income levels. ${ }^{56}$ The Justice Department statistics measure only the income of victims (not perpetrators) and appear totally consistent with this "victim-entrapment" hypothesis.

However, the older NFVS data do not focus on victims' income; they measure perpetrators' income levels. Similarly, Gelles, Wolfner, and Lackner, in their discussion of sociological "profiles" of men who batter women, find that the social science studies indicate that low-income men or men residing in low-income households "have higher rates of abusive behavior toward women" (1994: 4). What does this mean? Must we conclude that poor men are more malevolent toward women than wealthier men? I don't believe so. At most, any increased abusiveness among lower income men is likely to reflect the greater "stresses" of unemployment, poverty, poor education, community violence, racism, and the host of circumstantial ills suffered by the poor. Significantly, stress levels have also been correlated with rates of abuse (ibid.). ${ }^{57}$ Thus, in response to the New York City homicides study, Jeffrey Fagan, director of the Center for Violence, Research and Prevention at Columbia University's School of Public Health, commented that "[t]he myth of classlessness of domestic violence is one that has persisted since the $1960 \mathrm{~s} \ldots$ the truth is, it is a problem of poverty, associated with other characteristics like low marriage rates, high unemployment and social problems" (Belluck 1997). While I believe it is an overstatement to call domestic violence merely "a problem of poverty," I do believe we must now recognize that its prevalence and effects may be different at lower income levels. 
The notion that poverty spawns numerous "secondary" ills is not new and has long been touted by progressive poverty analysts (Harrington 1963: 119-135; see also Sherman 1994). Moreover, the link between economic stress and violence against women is lately also beginning to be noted in white middle-class communities experiencing sudden economic devastation. Betty Friedan has persuasively pointed out several instances in which violence against women escalated in the wake of sudden employment dislocation in particular communities (Friedan 1995: 26). She theorizes that when economic stress is severe enough, women (who are presumably perceived as "lesser") become the scapegoats. It also appears that greater emphasis is placed on aggressive male behavior, for example, in sports, as an alternative path to recognition and success. Unfortunately, such male aggression is often turned upon women (ibid.).

However, in applying this perspective to domestic violence, we need not lose sight of the feminist insight about battering's source in patriarchal values. Belief that poverty or severe economic stress contributes to battering need not be inconsistent with the fundamental conviction that battering is the product of powerful and universal cultural messages that support male dominance of females. Nor does it suggest that battering is not a problem in the middle and upper classes. Surely, patriarchy and poverty can coexist as two powerful social forces which result in a tendency toward male abuse of women throughout society, which might be exacerbated among the minority poor, who suffer far more "slings and arrows" and have few, if any, avenues for self-fulfillment.

Thus, while the Straight Out of Brooklyn portrayal of a poor black man who beats his wife is unsatisfactory (1991), it seems we have yet to envision the "story" of a batterer which would realistically synthesize the roles of male prerogative, woman derogation, and the impact of poverty in his abuse of women. Since the oppressions of poverty (combined with historic and contemporary racism) are ambient and shape not only individuals, but families, generations, and entire communities, such a story would require us to hold in our minds many levels at once: the historic and societal privations of racism and poverty, the way those privations across a community shape individuals, the patriarchal belief system that teaches that males are entitled to control and possess females, as well as an understanding of the personal feelings and motivations of the individual perpetrator and the victim. Such understanding might well lead to compassion for both. However, such compassion, if it truly incorporates an understanding of the intentionally derogatory nature of abuse, would not be the equivalent of excusing the perpetrator or minimizing his misdeeds.

Weaving these threads of understanding into our advocacy on behalf of battered women has the potential not only to improve the lot of poor battered women subjected to welfare reform, but also to strengthen the battered women's movement. First and foremost, a deeper grasp of the roles of poverty and race in battering among poor people of color may 
enhance advocates' empathy for poor communities of color, willingness to work directly with poor communities and activists, and those communities' mobilization against battering. ${ }^{58}$ In particular, as discussed in section IV(B)(2) above, more fully grasping the pain of poverty and racism might enable us to better understand those of our clients who feel loyalty to their abusers in part out of loyalty to their community and sympathy for the disadvantages they face.

A more multi-dimensional view of batterers may also improve advocates' relationships and work with battered women of all races and classes. The tendency of advocates to "demonize" batterers often creates tension and distance between survivors and their advocates (Mills 1996: 46). Since battered women so often feel conflicted about their abusers, whom they often still care for, their advocates' or attorneys' attitude that the abusers are purely heinous can make it difficult for clients to fully trust and confide in their representatives. Acknowledgment of the ways the batterer is also oppressed could be empowering for many survivors, and might relieve the pressure from advocates to completely reject their abusers. The movement and the literature have dealt with battered women's ambivalence toward their abusers primarily from the perspective of outsiders, seeing it as a reflection of the victims' inaccurate (even if understandable) perspective, which is distorted by their abuse or is driven by their personally (sometimes unhealthy) conflicted feelings of love for an intimate partner (Dutton 1993: 1224-25; Abrams 1995: 367, n. 246). Advocates have also acknowledged that many women's ambivalence about taking action is due to a legitimate and realistic fear of retaliation (Davies 1994; Mahoney 1991: 1; Meier 1993: 1343-47). However, advocates have been less able to acknowledge that a woman's ambivalence may also reflect facets of the abuser which are genuinely loveable and/or elicit legitimate sympathy in their partners (Schechter \& Jones 1992: 14). If advocates were more able to grasp a complex vision of men who batter, as sometimes loveable or deserving of pity, we might be better able to relate to and empathize with our ambivalent clients. Women could then see their action against the abuse as challenging the actions - but not necessarily demonizing the person - of the abuser. We might experience less attrition from clients dropping out because women may feel more able to challenge abuse when they feel that their conflicting loyalties are understood and validated. Moreover, validation of their ambivalent view of their abuser may be empowering by relieving abuse survivors of the self-criticism and feelings of "weakness" or inadequacy they often feel about their own ambivalence.

Developing a more complex grasp of batterers would also meet what has been a growing call in the battered women's movement for less simplistic, stereotypical paradigms of battering (Cahn \& Meier 1995: 353-56). In the early days of the movement, it was sometimes necessary to convey the notion that batterers were "monsters" in order to get judges or policy makers to treat domestic violence as a serious problem. However, this image 
the perspectives of both movements must be enlarged to recognize the multiple layers of victimization which both poor women and men endure.

On an urgent political and policy level, at this point in time, while there can be no assurance that addressing battering among poor women of color will not result in some of the demonizing and dismissing which advocates have historically feared, it seems clear that the risk is one that must be taken. As a practical matter, implementation of the new stringent restrictions on welfare without attention to the interaction of domestic violence and poverty threatens to further endanger poor battered women and to force some back into abusive relationships. At the same time, perhaps serendipitously, the current political climate which is so hostile to the poor may be more receptive to the needs of battered women. ${ }^{65}$ In the wake of the Violence Against Women Act of 1994, itself pushed through with strongly bipartisan leadership, it appears that consciousness and support for the issue of domestic violence among policymakers may now be both broad and deep enough to address domestic violence among the poor without its being dismissed as "merely" a poor people's problem. Thus, in the course of a meeting in May 1996 to discuss the impact on battered women of prospective welfare "reforms," a Republican staffer noted that "there are no Republican battered women or Democratic battered women. .." This view may not be just one person's: In July 1996, the Wellstone amendment to the Senate welfare reform bill, which required the state welfare programs to screen for battered women and provide various accommodations for them, passed unanimously in the Senate (U.S. Congress 1996: S8141-42). Given the punitive nature of the law being amended, the senators' unanimity on behalf of softening the blow for battered women was striking. That this "requirement" was ultimately converted by the conference committee to a state "option" was perhaps less surprising, but not entirely inconsistent (ibid.).

\section{A WORD ON STRATEGIES}

The foregoing discussion has been largely analytic, attempting to shift how we think about domestic violence and poverty. In this section, I briefly discuss some concrete policies and actions that have been pursued or may be considered in the wake of the synthesis I have urged.

\section{A. WELFARE POLICY}

\section{Current Advocacy and Policy Development}

Under the new welfare regime ushered in by the federal PRA, domestic violence may have even more devastating ramifications than it already has for its victims. Insofar as the new law requires recipients of public assistance 
to work, violence which previously "only" caused a victim to lose her employment or job training can now also lead to the loss of her public assistance. If they do not acknowledge the role of the abuser, state welfare agencies may become the unwitting colluders with batterers who seek to "punish" their partners or former partners. Moreover, what has always been taken for granted by those who work with battered women, that a mother could leave an abuser and depend on welfare to support herself and her children if necessary, is no longer the case. ${ }^{66}$ Preventing the elimination of this "safety net" for battered women and their children, and the extension of abuse to the welfare system, is now going to depend on effective advocacy for battered women with respect to welfare policy, legislation, and implementation at both the state and federal levels.

Prior to adoption of the Family Violence Option (FVO) described further below, domestic violence was explicitly and implicitly relevant to welfare reform in two provisions of the PRA: (1) the " $20 \%$ hardship exemption" which allows states to exempt up to $20 \%$ of their welfare caseload from the five-year lifetime limit on welfare, and which specifically mentions battering (PRA 42 USC § 608(a)(7)(C)); and (2) the "good cause" exception to the requirement that welfare recipients "cooperate" with paternity and child support enforcement (PRA § 333(3); 42 USC § 608(a)(2)). The child support good cause provision existed under prior law and had been defined in federal regulations as including domestic violence (narrowly defined) (45 CFR $\S 232.42(\mathrm{a})(1)(\mathrm{iii}),(\mathrm{iv})$ ). However, based both on past history and the political context of the PRA, neither of these provisions could be expected to be generously applied to battered women, ${ }^{67}$ given the political context and sea change in welfare policy and culture embodied in the PRA's elimination of the safety net for most recipients. In any event, even full implementation of these two provisions as applied to battered women would still leave many women in the position of being required to meet welfare program requirements that put them in danger of abuse or which they are unable to meet due to abuse.

Therefore, beginning in mid-1995 and continuing through passage of the PRA in 1996, national domestic violence/welfare advocacy focused on integrating attention to domestic violence into the more core provisions of the PRA. In October 1995, a meeting of the National Task Force on Women, Welfare and Abuse undertook intensive brainstorming about how welfare agencies might "ideally" address domestic violence. Subsequently several (non-binding) resolutions were introduced by Senator Paul Wellstone and Representative Lucille Roybal-Allard, reflecting some of the core principles developed by the Task Force. The Joint Resolution on Domestic Violence and Welfare introduced in May 1996 called for the screening, identification, and referral of battered women for legal and counseling services, as well as "good cause" waivers of various requirements, such as work requirements, time limits, and child support cooperation, where appropriate. A condensed version of the same resolution, calling simply for 
Congress and the states to "address the impact of domestic violence on welfare recipients" in any welfare reform program, was unanimously adopted by the House Budget Committee and ultimately passed both Houses as part of the (non-binding) Budget Reconciliation Bill (Pollack \& Davis 1997; 1084, nn. 22-24).

Finally, in July 1996 the Senate unanimously adopted an amendment to the PRA (the "Wellstone/Murray Amendment") which mirrored the Joint Resolution in requiring the states to screen welfare applicants for domestic violence history, refer domestic violence survivors to services, and to waive where appropriate child support cooperation requirements, time limits, work requirements, and any other program requirements. The Wellstone/ Murray Amendment's mandate was converted to a state "option" in conference committee before final passage of the PRA (Pollack \& Davis 1997: 1085 and nn. 30-31). Hence the Wellstone/Murray Amendment is now known as the Family Violence Option (FVO).

The FVO as finally adopted reads in pertinent part as follows:

At the option of the State ... [States may]

(i) screen and identify individuals receiving assistance under this part with a history of domestic violence while maintaining the confidentiality of such individuals;

(ii) refer such individuals to counseling and supportive services; and

(iii) waive, pursuant to a determination of good cause, other program requirements, such as time limits (for so as long as necessary) for individuals receiving assistance, residency requirements, child support cooperation requirements, and family cap provisions, in cases where compliance with such requirements would make it more difficult for individuals receiving assistance under this part to escape domestic violence or unfairly penalize such individuals who are or have been victimized by such violence, or individuals who are at risk of further domestic violence. (42 USC $\S 602(a)(7)$ )

The FVO received the subsequent endorsement of both President Clinton, who in October 1996 issued a presidential directive directing the attorney general and the Department of Health and Human Services (DHHS) to take steps to educate and support states' implementation of the FVO, and of Secretary of Health and Human Services Donna Shalala, who (in partial fulfillment of the directive) sent a letter to each state's governor urging them to adopt and implement the FVO (U.S. Office of the President 1996a, 1996b; Shalala 1996).

Despite this show of support by federal officials, concerted advocacy remains necessary at both federal and state levels in order for the FVO to be adequately implemented at the state level. Since passage of the PRA, a number of ambiguities have arisen concerning the interpretation of the FVO in interaction with other provisions of the PRA. In particular, some states have feared they might face penalties for failure to meet mandated "work participation" percentages, if they do in fact grant FVO waivers to battered women. States have also expressed some concern about whether FVO waivers will be limited by the $20 \%$ cap on "hardship exemptions." Perhaps 
in part because of Congress' expressed hostility to the DHHS taking an active role in interpreting the new law (42 USC $\$ 617$ ), no clear guidance has been forthcoming on these questions from the DHHS, despite the presidential directive, Shalala's letter, intensive advocacy by domestic violence advocates involved in the legislation, and the clear intent of the FVO. As a result, a new Sense of Congress Resolution reiterating and clarifying the purposes of the FVO and good-cause waivers was introduced and adopted by both Houses of Congress (U.S. Congress. Senate 1997; U.S. Congress. House 1997). In addition, Senator Wellstone and Congresswomen Roybal-Allard and Sue Myrick introduced Senate Bill 671 and House Bill 1950, a technical amendment to the PRA which specifies that FVO waivers are not to be counted within the $20 \%$ hardship exemption or the work participation percentages (Senate Bill 671). ${ }^{68}$

Despite these ambiguities, "a number of states, including Connecticut, Florida, Indiana, Kentucky, Maryland, Missouri, Montana, New Hampshire, North Carolina, South Dakota and Tennessee have adopted all or part of the FVO" (Pollack \& Davis 1997: 1085). In addition, state welfare plans may be amended at any time, to provide for adoption of the FVO (or any other change) (ibid.: n. 34). However, even in states which have adopted it, much remains to be determined about how battered women will be dealt with in these states' welfare programs. Will states merely notify or screen applicants for battering, without offering waivers? How will they screen or notify, how will they make referrals to services, and most importantly, how will they make waiver decisions? Advocacy at the state level is thus critical, both for states that have already adopted the FVO and those that
have not. ${ }^{69}$

Such advocacy will be needed on three levels: First, advocacy can ensure that states do in fact exercise their federally offered "option" to screen public assistance applicants for a history of abuse and provide some accommodations for those who need them. Second, advocacy at the program implementation stage will be critical to ensure that the screening is appropriate, sufficiently broad, and sufficiently confidential, and that waivers of federal work requirements are implemented in as fair a manner as possible (Pollack \& Davis 1997). The most effective programs both for recipients and for the goal of reducing welfare dependence, will be those programs that, rather than merely "exempting" battered women from the work requirements, offer referrals to legal and other services which can assist women to become safe, and counseling which can assist them to recover from the trauma and maintain or develop employment skills (see generally Murphy 1997). And third, individual welfare applicants will need advocacy on their behalf when they are denied waivers they are entitled to under the law. Thus, it will be critical for battered women's advocates both to participate actively in the development of state laws and welfare programs, and to expand their individual advocacy on behalf of battered
women into the welfare arena. 


\section{Philosophical Concerns about Welfare Advocacy on Behalf of
Battered Women}

As we move forward from here, it will be important to consider the benefits and drawbacks of the approaches which have so far been taken in the legislation described above. In the view of most of the advocates involved in the process, insertion of the domestic violence issue into the process of welfare reform by creating a specific set of accommodations and requirements for battered women has been a necessary stopgap in the face of the freight train of welfare reform. It is the most straightforward, expeditious means of reducing the harm to battered women from draconian welfare reforms. Insofar as the cause of domestic violence still seems to be politically popular on both sides of the aisle, it may also be the most effective and successful strategy for integrating the welfare and domestic violence issues in the political process.

However, creating a special exception for battered women within the larger welfare reform initiative is potentially a double-edged sword. For battered women themselves, being treated as "special" or more "victimized" than others has often backfired, resulting in their treatment as mentally disturbed and not functional or competent (Meier 1993: 1306-11). Provision of special services for battered women and, more significantly, extensions of the time required to get a job, are difficult to distinguish from a "disability" exception for battered women. It might be argued that singling out battered women for special treatment in welfare policy implies that they have a "disorder" which entitles them to exemption from the general requirements. This potential could intersect destructively with the growing tendency to look for "objective," that is, scientific, measures of whether or when a person has been abused. Increasingly, a clinical diagnosis of PTSD is being required before battered women are granted various remedies, despite the fact that full-blown PTSD is not applicable to all battered women (Dutton 1993), and, as a clinically diagnosed "disorder," is potentially more stigmatizing than the mere fact of having been abused (Raphael 1996d; Davies 1996; Stark 1995: 975). It is probably not unrealistic to suspect that state laws or programs, acting bureaucratically and without sufficient input from advocates, might adopt a clinical definition of battered women, thereby contributing to the pathologizing and stigmatizing of the issue, discouraging women from disclosing it, and crippling any domestic violence policy the state adopts. Given the overlap between the child protection bureaucracy and the welfare bureaucracy, the costs of such pathologizing to women could be drastic and very real.

While these concerns call for caution, it is my view (and that of many other concerned advocates and scholars) that the risk of stigma and pathologization exists every time battering is discussed. Although we might choose not to bring up the problem in some circumstances because we fear responses will be inadequate or even destructive, we cannot hide the issue in 
the context of national welfare reform. Moreover, silence about domestic violence means allowing millions of battered women to be further "battered" by the punitive elimination of public assistance after they have been abused and lost their job, or after they refuse to "cooperate" with child support enforcement out of fear of abuse. Although some might argue that rather than focusing on battering, we should focus on oppression of women generally, or the horrors of poverty, it is clear that the concreteness and specificity of violence and its impact offers a compelling justice claim. Moreover, the story of the battered women's movement is a story of creative and dedicated feminists growing and adapting their advocacy and understanding in response to social conditions. The challenge of combating excessive pathologization is one which has already begun to be met (see, for example, Stark 1995; Mahoney 1991). We must push the issue forward and do our best to minimize negative fallout.

Providing a special exception for battered women is also troubling from the perspective of other, non-battered welfare recipients. There is a danger that singling out battered women for special exemption from the draconian welfare reforms imposed on everyone else recapitulates the distinction between "worthy" and "unworthy" recipients which has plagued social welfare policy from its inception and has enabled the demonization of the poor (Davis 1993; Gordon 1994: 4-7). Indeed, it is likely that the Wellstone Amendment's unanimous acceptance by the Senate reflected precisely the assumption that, while these women may be "worthy" of public assistance, others are not. If one does not share the moral premise of the current welfare reforms that poverty is the fault of the poor, but rather believes that life in the urban ghetto (or rural poor communities) itself inflicts numerous ills that keep people poor, one must pause before advocating that particular sub-groups "deserve" better treatment than others. While I share this concern, my hope is that domestic violence can be a "wedge" issue: Expanding the debate to acknowledge any ways in which welfare recipients are not responsible for their own plight may pave the way for a broader, more empathic and less demonizing discussion of the many different problems of poverty faced by those who need welfare. And again, allowing all to suffer rather than saving some does not seem a reasonable price to pay, whatever our empathy for the poor.

\section{B. OTHER POLICY IMPLICATIONS}

\section{De-Criminalization?}

My call for greater compassion for poor men who abuse women, and for reducing the demonization associated with battered women's advocacy, might raise the following question for some readers: If new thinking is required, and poverty is at least some part of the problem of domestic violence among the poor, is it time to abandon criminal sanctions and to 
turn to constructive anti-poverty measures and programs, that is, to use a carrot rather than a stick? Surprisingly, this very question has lately begun to be raised by a number of committed advocates for battered women. Jill Davies, a longtime legal aid lawyer and respected activist for battered women, has questioned the battered women's movement's historic emphasis on criminal sanctions to the exclusion of a more "woman-defined" advocacy, in which sanctions are just one of a variety of safety empowerment strategies (Davies 1993; see also Davies forthcoming 1997: 49-50, 55, 148-49, 202-3). Stronger reservations about the criminal justice approach from a psychological and counseling perspective are articulated by Linda Mills, an interdisciplinary scholar and teacher in the field (1996: 1233-38). Coming not from the forces of the status quo or patriarchy, but from advocates of battered women and against patriarchy, this challenge to the battered women's movement's conventional wisdom demands serious thought.

Without attempting a full disquisition on this question here, for purposes of this essay it is important to state that I do not believe that the "synthesis" called for here implies abandonment of criminal sanctions. On the contrary, I believe that abandonment of the criminal sanction would essentially be abandonment of the lessons of the battered women's movement altogether. For all the reasons articulated earlier in section IV above, maintenance and possibly enhancement of criminal sanctions is both an essential element of battered women's advocacy and is critical to reducing domestic violence. This view rests not only on the importance of the criminal law as the "moral educator" of society, and embodiment of every citizen's right to exist in civil society rather than the law of the jungle (Heyman 1991: 512-30), but perhaps equally on the fact that removal of the criminal sanction is not a neutral act, but unavoidably sends a message as well. While criminal sanctions in themselves may not be sufficient means of stopping domestic violence, to create an exception to the general principle that every citizen has the fundamental right to not be attacked, can only encourage more such violence. The criminal law is the necessary backdrop, or framework, within which the social struggle over battering must take place.

However, holding abusers to the standards of the criminal law, and sanctioning and even branding them "criminal," need not be inconsistent with developing greater compassion or understanding for the privations of poverty and racism they may have suffered. As I have suggested, a less demonizing attitude toward abusers can broaden our understanding and sympathy for those of our clients who feel ambivalence toward and love for their abusers. It may also help us to respect and support choices those clients may make, not to prosecute or seek harsh sanctions against their abusers. In individual cases, then, we must try to support women who make the choices we (think we) would not choose (Davies forthcoming 1997: 104). We may also go further and become advocates on poverty issues which affect men as well as women. However, as advocates for 
social policy on domestic violence, we can at the same time support clear and unambiguous criminal sanctions as society's measure of the moral heinousness of the offense. We must cultivate "multiple consciousness" (Matsuda 1988), in which the individual, compromised, and social, ideal points of view can and must coexist. As Christine Littleton has stated (1989: 47-56), the challenge for feminists in this field is one of "transition": we need to both move society and individuals within it toward a place where equality and respect between men and women is a given, but before we get there, we will have to work with individual women and men for whom demanding this kind of perfection does violence to their souls. We must continue to hold up the "ideal" of equality and respect while working respectfully with constrained men and women within the non-ideal world.

\section{Other Policies}

If we are truly simultaneously to entertain recognition of both the moral heinousness of domestic violence and the broad, community-wide, socioeconomic disorder within which it takes place among the poor, we should, while maintaining a firm criminal justice response, simultaneously offer a response to that socioeconomic devastation. As a domestic violence - and not a poverty - expert, I do not presume to prescribe answers to poverty in the urban ghetto. However, I do want to suggest that feminists and battered women's advocates need to be thinking about ways social welfare policy might engage and work with the men in our clients' lives. Jill Davies has commented, "what good is it if we get him to stop abusing our client and he just goes on to the next victim?" (Davies 1996). Too many of us know that is what we accomplish with much of our advocacy on behalf of individual battered women. Moreover, our clients often do not want to be alone the rest of their lives. Not unreasonably, they want a decent relationship with a caring partner. Again, if we are to truly represent their interests, we need to think about what kinds of welfare policies would offer some constructive role for the male partners of women receiving welfare.

One such possibility might be employment assistance for the partners of the women on public assistance. As others have noted, one of the best ways to encourage an abuser to stop obstructing his partner's work efforts might be to give him his own avenue for "success" (Friedan 1995: 26). It may be that job training and placement should be made available not only for women receiving welfare, but also for the fathers of their children (Raphael \& Tolman 1997: 27). Such a policy would need to be available to all, not just partners of battered women, lest battering become a "ticket" to extra services. It would also require careful consideration, so that it does not enable further victimization of women in unforeseen ways. However, conceivably, such services might be made a part of the new, more aggressive child support enforcement which is currently contemplated. 
Of course, such a policy of offering proactive assistance to "deadbeat" fathers in a non-punitive manner seems dramatically out of step with the punitive "spirit" of welfare reform. But who knows? Once we start radically reconceiving progressive causes, it may just become possible to radically reconceive welfare as a social and economic policy designed to end poverty.

\section{CONCLUSION}

Meaningful attention to the connection between domestic violence and poverty potentially invites a different kind of discussion of "character" and "behavior modification" than the welfare reform discussion which has until now been polarized between conservative and poor-bashing welfare reformers and progressive anti-poverty opponents of welfare reform. This new discussion should be driven by both feminist and poverty activists' values and must seek to liberate poor people from the oppression of both domestic violence and poverty. Full integration of the lessons of the domestic violence movement into the poverty and welfare discussion can energize the fight against conservative welfare reforms which, if freely implemented, will perpetuate both the poverty and violent victimization of women and children. A synthesis of poverty and domestic violence perspectives also offers new life and more complex politics for the anti-poverty and battered women's movements, both of which may be renewed by the more nuanced, sophisticated, and mature perspectives on battering and poverty that will inevitably flow from serious consideration of the interaction between them.

JOAN MEIER is a Professor of Clinical Law at the George Washington University Law School and the founding Director of the Domestic Violence Advocacy Project. Professor Meier has been an activist, litigator, and writer in the field of domestic violence in Chicago and Washington, D.C., for the past fourteen years. In the summer of 1996, she was the primary drafter of the Battered Women's Employment Protection Act recently introduced in both Houses of Congress, and was a co-drafter of the Family Violence Option contained in the Personal Responsibility and Work Opportunity Reconciliation Act of 1996 (welfare reform legislation). She is a member of numerous local and national commissions and advisory boards, including the Mayor's Commission on Violence Against Women, and the Advisory Board for the ABA Commission on Domestic Violence's Curriculum Project. Professor Meier received her A.B. from Harvard University and her J.D. from the University of Chicago.

\section{NOTES}

1. In one of the first legal articles to explicitly address the connection between domestic violence and entrapment in poverty, Lucie White (1993) examined the common assumption that women on welfare could avoid welfare by work or remarriage if they wanted to. She identified domestic violence, among other 
things, as an obstacle to the latter. The role of domestic violence in obstructing poor women's employment first received national attention at a conference sponsored by the NOW Legal Defense and Educational Fund ("NOW LDEF") in April 1995. The "Leadership Summit: The Link Between Domestic Violence and Poverty," the first of its kind, brought together poverty workers in the field with poverty theorists and domestic violence thinkers and practitioners to begin a dialogue and develop answers to the conservative attack on welfare recipients. Since then a series of national and local working groups and research conferences on women, welfare and abuse, primarily initiated by the Chicago Taylor Institute and NOW LDEF, have furthered thinking about welfare policy and battered women, and developed a series of federal and state legislative and policy initiatives on welfare reform. See section VI, infra.

2. It is notable that many of the dysfunctions of which "welfare mothers" have been accused, such as substance abuse, depression, and neglect or abuse of children, are common responses to domestic violence (Dutton 1993: 1221-22; Cahn 1991: 1055-58).

3. I use the term "dependency" literally, to refer to discrete circumstances where the welfare recipient lacks any other financial means of survival for any number of reasons, often beyond her control. I do not intend to imply the pejorative connotation frequently given the phrase "welfare dependency," where the "dependency" is implied to be permanent and disabling and the recipient's fault (Gordon \& Fraser 1994: 309).

4. In this essay I refer to "conservative reformers" to include both Republican reformers in the current Congress and the many Democrats such as President Clinton, who have joined the call to "end welfare as we know it" and who do not explicitly challenge the assumption that welfare and weak character are the causes of most of the social ills of the poor.

5. For instance, Senator Daniel Patrick Moynihan stated in 1990 "[o]ur problems do not reside in nature, nor yet are they fundamentally economic. Our problems derive from behavior" (Moynihan 1990: S14417). Many supporters of welfare reform view as poor people's problematic "behavior" the bearing of children, presumably by "choice," to be supported on welfare (Fineman 1991: nn. 11-13 and accompanying text). Therefore, conservative "virtuecrats" advocate "formation of good character as an urgent aim of government" (Kinsley 1995: 37-38).

6. Of course this assumes that victims of domestic violence will not be blamed for their own victimization, a tendency which has been reduced in the past few years but is still far from eliminated (Meier 1993: 1352).

7. In referring to the "poverty" or "anti-poverty" movement, I refer to activists in legal services programs serving the poor, policy advocates, and writers and thinkers, including many criminal defense lawyers, who are some of the most vocal and racially aware defenders of poor men. The battered women's movement is easier to define, in that there is a small core of longtime nationally known activists on domestic violence, and a relatively small number of national and local programs dedicated specifically to that issue. However, my references to each movement are really intended to refer to a perspective, philosophy or belief, as described in the text above: in essence, that poverty (and racism) or domestic violence (or sexism), respectively, is the dominant form of unjust oppression in society, and that focusing on one undermines advocacy against the other. In fact, some longstanding activists in the battered women's movement have voiced the concerns I attribute herein to the "poverty movement." My challenge, then, is directed at the belief that the principles and values of each cause are mutually exclusive and harmful to each other, wherever held.

As becomes clear in the remainder of this essay, I am not neutral in this debate, but speak from the perspective of a longtime hattered women's artivict 
and current director of a domestic violence clinic at The George Washington University Law School. However, as a one-time (albeit brief) legal services lawyer, I also feel substantial loyalty to the legal services mission and the antipoverty movement's goal of eradicating the injustices of poverty and racism. This critique of both movements grows out of my strong regard for each and my desire to synthesize their seemingly conflictual orientations.

8. Isolated voices have previously raised the intersecting concerns of domestic violence and poverty (Zorza 1996a: 1), but only recently has there been a national coalescing of attention to these issues among battered women's movement activists and scholars.

9. One important exception is the work of Kimberle Crenshaw (1991: 1245-65), arguing that the confluence of disadvantages of race, gender and class profoundly affect the experiences of many battered women and have been inadequately addressed by both the feminist and "anti-racist" movements. In addition, the connection between domestic violence and homelessness was noted in the literature some years ago (Zorza 1991: 420). However, these analyses of domestic violence have not substantially affected perspectives on either domestic violence or poverty law, and have been minimally integrated into discussions of welfare reform.

10. "Social welfare policy cannot be fully understood without recognizing that it is fundamentally a set of symbols that try to differentiate between the deserving and undeserving poor in order to uphold such dominant values as the work ethic and family, gender, race, and ethnic relations. In this sense, welfare policy is targeted not only at the poor, but equally at the nonpoor, through the symbols it conveys about what behaviors are deemed virtuous or deviant" (Handler \& Hasenfeld 1991, quoted in Lynn 1993: 89). Historically welfare policy has blatantly sought to regulate the "morals" of AFDC participants, on the view that women who were not "fit mothers" were not "worthy" recipients of government largesse (Davis 1993: 9; Gordon 1994: 43-44, 304). At its inception, welfare involved intentional incentives for two-parent families and disincentives for and stigmatization of single motherhood (Gordon 1994: 7-12).

11. See notes $52-54$, below.

12. See pages $232-237$, below. The need for feminists to incorporate recognition of economic differences and realities into our analysis of harm and victimization has been forcefully articulated by Lisa Brush (1997: 246, 251), who argues that such a synthesis will also answer the attacks on "victim feminism" by many feminist critics.

13. Typical state regulations included "man-in-the-house" rules, which denied benefits to any mother who frequently "cohabited" with a man, regardless of whether he provided any support (Davis 1994: 60-61). Although the more blatant and baldly moralistic of these regulations was struck down by the Supreme Court (King v Smith 1968; Lewis v Martin 1970), contemporary practice in most states still often penalizes welfare recipients for the presence of another adult in the home; thus, both recipients and caseworkers continue to propagate the fiction that welfare mothers are "single" (Cunningham 1996).

14. Raphael (1996a: 1) suggests that welfare grants are insufficient for women to support themselves and their children, causing them to need to depend on a man for additional assistance. It is likely that not only economics, but love and a lack of meaningful options are all at play in women's continued liaisons with abusive men (Davies 1996).

15. Among my clinic's caseload, it is not uncommon to hear that clients have been forced to leave a job because of abuse, including stalking and harassment on the job by the abuser or bruises the employer found unacceptable. In the majority of 
such cases, the client was forced onto welfare, but not necessarily back to the abuser. Whether the abuser intends to regain a relationship with the victim or not, and whether or not he succeeds, does not change the fact that abusers do seek to destroy women's autonomy and independence, and frequently succeed in forcing them onto welfare.

16. Definitions of "current" vary from study to study, but most confine the question to abuse within the past year; one goes back two years (Raphael \& Tolman
1997: 11).

17. The variations among the studies are likely to be attributable to different definitions of abuse; the Chicago study which found "only" $34 \%$ of the population had been abused as adults defined abuse more narrowly than the other three studies, to include only "severe physical aggression," excluding "throwing objects at the respondent, pushing, grabbing and slapping" (Raphael \& Tolman, 1997: 15).

18. For example, the Mid-Iowa Community Action program found that $22 \%$ of participants were current domestic violence victims, and $51 \%$ were past domestic violence victims (Raphael 1995: 3-4). Similar data have been found by other programs (Raphael 1996a: 11-13, citing Colorado Springs welfare-to-work program study). The first statewide study of public assistance recipients found that $60 \%$ of all recipients had been physically or sexually abused as adults (as compared to $35 \%$ of a comparison population) (Weeks \& Webster
1993).

19. Two dangers are associated with discussions of PTSD and battered women. On the one hand, the label can be used to pathologize battered women, potentially threatening women's custody of children (Meier 1993: 1314; Davies forthcoming 1997: 21,94). On the other hand, there has also been an emphasis on requiring a formal clinical diagnosis of PTSD before an individual is recognized as severely abused or entitled to any remedies that flow from that label (Dutton 1993: 11981201; Raphael 1996d). Many women suffer some, but not all, of the symptoms required for a full diagnosis of PTSD. Such women should not be deprived of
relevant legal remedies or other assistance.

20. Reliance on these statistics should take account of the fact that the studies were assessing only individuals who had self-identified as battered in the context of seeking services or participating in the research study. To the extent that the studies did not include women who had not sought such help, possibly because they were more able to end the abuse on their own (and presumably less traumatized) or because they were more trapped and less able to seek help (and presumably more traumatized), the accurate percentage could be either higher or
lower.

21. A disturbing proportion of study respondents have also been victimized as children (Raphael \& Tolman 1997: 4, 7, 11), and undoubtedly some of them suffer PTSD as a result. However, for purposes of the argument made here that poverty and the need for welfare are corollaries to abuse, which is often intended by the abuser to create such poverty and welfare dependency, I limit my focus to abuse experienced by poor adults.

22. As early as 1984, Charles Murray in his book Losing Ground (1984) blamed welfare for the prevalence of illegitimate children in the urban ghetto. More recently:

[d]uring their Administration and throughout the 1992 Presidential campaign, President Bush and Vice President Quayle claimed that the welfare initiatives of the 1960s are responsible for the persistence of poverty in the United States and the urban problems demonstrated so graphically by the Los Angeles riots this spring. . . [and that welfare mothers] are economically and emotionaliy atrophied because of their "dependence" on welfare. (Williams 1992: 719-720) 
Subsequently, Newt Gingrich, House of Representatives Majority Leader: suggested that a woman's deliberate drowning of her two sons was another example of dysfunctional behavior produced by welfare (Scheer 1995), and presidential candidate Bob Dole (in a bizarre turnabout of the then-newly publicized data on welfare and domestic violence) blamed welfare for spawning increased domestic violence (Seelye 1996).

23. For a discussion of some additional policy issues, see Davis and Krahan (1995).

24. Other answers to the reformers' assumptions have been offered, but have hac little impact on policy. While domestic violence is by no means the whole, or a1 exclusive, explanation for welfare recipients' behaviors, it is a new explanation which may have some persuasive power to the conservatives, which othe explanations have lacked.

25. This provision of the PRA provides grants to states for facilitating noncustodia parents' visitation with their children, by means of mediation, etc. At a recen national conference on child support enforcement, agency personnel fror several different states informed me that child support enforcement agencie are already becoming involved in obtaining visitation for non-custodial father as a kind of enticement or exchange for compliance with child support (di: cussions with participants at the Eastern Regional Institute for Child Suppor Association Annual Conference, 4 May 1997, Buffalo, New York). Such prc grams typically require mediation between the parents over child visitation These practices put both battered women and their children at risk if the are implemented without adequate identification of domestic violence an (i) exemption from the mediation process where the mother fears the father, an (ii) adequate protective conditions or restrictions on visitation where the fath poses a risk to the child.

26. More than half of the men who batter their female partners also abuse the children, and seventy percent of injuries inflicted on children by male pe petrators are severe (Hart 1992: 33). Moreover, the majority of children battered mothers who witness abuse of their mothers suffer emotional affec comparable to children who are directly abused (ibid.; Zorza 1991: 424-25).

27. State child exclusion policies are being challenged as unlawful and constitution in several state courts (Davis 1993; Friedman 1995).

28. Some studies suggest that $59 \%$ of battered women suffer sexual abuse (Zor 1996b: 1120). Among welfare recipients in Passaic County, New Jersey, 74.7\% the battered women have also "experienced some forms of sexual traum (Raphael \& Tolman 1997: 4). These numbers are likely to be underestimat sexual abuse is even more under-reported than physical abuse (Bachman Saltzman 1995: 1, 6)

29. It is likely that, if poor women felt free to control their own destinies, they wor bear fewer children. Studies of third-world populations have indicated that women acquire greater education, they bear fewer children (Vallin 1973; Lot 1977; Datta 1987).

30. The Passaic County study found that $30.8 \%$ of the battered, compared to 22.2 of the non-abused, stated they had been victims of rape; $34.7 \%$ and 23.8 respectively stated they had been victims of "sexual assault"; and $35.5 \%$ a $24.1 \%$ respectively stated they had been victims of "sexual abuse" (Raphael Tolman 1997: 4).

31. It is my view that the issue has not been more widely grasped precisely beca. real acknowledgment of the compromised nature of so many women's "choic concerning their sexuality and their lives, even apart from actual violence, wo radically threaten our assumptions about safety and freedom in the wor Indeed, feminist activists and theorists have been divided over the degree 
which women are, on the one hand, victimized and not in control, or on the other, active, self-directed agents of their own lives (Abrams 1995: 304-07; Brush 1997: 237-40). Notably, some of the strongest critics of "dominance feminism," i.e., the view that male dominance fundamentally defines and oppresses all women's existence, are women of color who feel that the "victim" label denies their strength and agency (Harris 1991). While this essay obviously focuses on the "dominance" side of the spectrum, I do not believe it is necessary to deny women's strength, capability, or agency merely because they have been assaulted or "victims" of what is, after all, a crime. I decline to impute the many levels of psychological incapacity to the word "victim," which many other feminists do. I also subscribe to the growing efforts to acknowledge the mixture of oppression and strength, coercion and agency, which characterize most women's lives (Abrams 1995; Mahoney 1991).

32. I do not share Professor Handler's equation of single parenting with "dysfunctions" like substance abuse (see Fineman 1994: 4-6).

33. As of approximately 1994, domestic violence could no longer be conceived of as a specialty distinct from the rest of feminism. It had begun to be incorporated into the work of both academic and political feminists who previously had not addressed it (Fineman \& Mykitiuk 1994). At around the same time, on the national political front, two of the leading feminist activist organizations in this country, NOW and NOW LDEF, expanded their scope to include domestic violence issues. Beginning with their push for the Violence Against Women Act, which culminated with its adoption in 1994, and continuing with their leadership in battling to soften the impact of welfare retrenchment on poor battered women, the new attention to domestic violence from national women's organizations has been a significant watershed in the development of the battered women's movement. Thus, from both scholarly and political vantage points, it is no longer unremarkable for political or academic feminists to neglect to mention domestic violence where it is relevant.

34. Indeed, many in the field were working actively on the intersection of welfare and domestic violence. Many advocates felt the 1995 conference on the connections between domestic violence and poverty was long overdue.

35. But see n. 9 , above.

36. This is not entirely surprising, since the battered women's movement was an offshoot of the women's movement, which was formed to empower women to fight specifically for women's rights separate and distinct from other issues (Pleck 1987: 182-85). However, one early exception to this pattern of single-issue specialization on domestic violence was the legal service office "Ayuda," a legal clinic in Washington, D.C., which offers combined representation in the fields of immigration, family law, and domestic violence for immigrant women. Interestingly, a number of law school clinical programs have similarly combined those two specialties, e.g., the Immigration Clinics at the City University of New York and St. Thomas University School of Law. Such programs may provide useful models for other types of cross-cutting advocacy.

37. Battered women's advocates' fear of raising domestic violence issues with the welfare bureaucracy because of its connection to the child protection bureaucracy was brought to my attention by Jody Raphael, Ann Menard, and Jill Davies (Raphael 1996d). As Pualani Enos argues, while children suffer terribly from witnessing abuse between their parents, removal from the only parent who is loving toward them in most cases will only compound their misery (Enos 1996: 231). This is not to say that children should never be removed from an abusive household; where they are direct victims, such removal is sometimes appropriate. However, removal of the abuser is always preferable if possible (ibid.). 
38. The rules of the local court in which I practice allow students to appear in court on behalf of clients only if they are indigent and their cases would not be accepted by the private bar (D.C. Court of Appeals Rule 48 (1995)).

39. Judith Lennett, former legal services attorney, when she was with the Massachusetts Coalition of Battered Women's Service Groups, spearheaded an effort which was responsible for initiating the Massachusetts study cited in Raphael \& Tolman (1997), and resulted in the adoption of the FVO by the State of Massachusetts.

40. I do not intend to suggest that this segregation of issues has been entirely a mistake; indeed, it has been productive and protective in many ways. However, I believe it needs now to be changed. I include myself in this critique.

41. The American women's movement has struggled not only with racial division but also with challenges from other disenfranchised sub-groups such as lesbians. In the past five to ten years, academic critiques of "mainstream" feminism as "essentialist" and exclusionary have proliferated (Harris 1991; Crenshaw 1991; Eaton 1994: 195). While some might disagree with such a characterization of the battered women's movement (Dobash \& Dobash 1992: 54), the new attention from NOW and NOW LDEF to poverty issues (see n. 33 above) may represent an expansion of the U.S. women's movement.

42. In May 1996, soon after advocates publicized to Congress and the public the new data linking domestic violence to poverty, precisely this type of "tarring" the poor with the "brush" of domestic violence occurred. In a campaign meeting with domestic violence activists, presidential candidate Robert Dole stated that the rise of domestic violence is attributable to the failure of welfare because welfare does not encourage able-bodied men to work (Seelye 1996). However, it may be more significant that Dole was severely criticized by battered women's advocates present at the meeting, and subsequently retreated from his claim (ibid.).

43. Davis Adams (1988), founder of "Emerge," one of the earliest and best batterers' counseling programs, has critiqued other approaches that are not pro-feminist such as the "insight," "ventilation," "interaction," and "cognitive-behavioral" models on the grounds that they do not hold batterers fully accountable for their decision to use violence. The efficacy of batterer programs is quite unclear, due to still inadequate data and mixed results (Tolman \& Edleson 1995). "The majority of batterer programs experience $40 \%$ to $60 \%$ dropout within 3 months" and up to $50 \%$ eventually fail to continue (Gondolf 1995: 5).

44. While data on both sides of the debate over the efficacy of criminal sanctions can be found (see, e.g., Sherman 1992; Zorza 1992), anyone who has worked with battered women has witnessed the profound impact that the failure to arrest can have on the confrdence of both the abuser and the victim. It seems tikety, and some research supports the theory that, even if actual incidents of violence are not reduced by initiation of criminal prosecution, victims' empowerment and their belief that they do not have to tolerate abuse are increased (Ford 1993). Moreover, most jurisdictions with pro-arrest or mandatory arrest policies have documented a marked drop in domestic homicides after those policies went into effect (Klein. 1997).

45. Lisa Brush argues that "the moralistic tenor of feminist anti-violence rhetoric is basically strategic ... [among other reasons] this moralism springs in large part from feminists' efforts to avoid naturalizing male aggression" (Brush 1997: $244-45$ ). While I share this perspective, I believe the moral focus of the battered women's movement is especially necessary to counter the moralistic culture of battering. 
46. New Left Poverty law ... focused on procedural and substantive aspects of government aid to the poor ... [and] left family inequity untouched ... Family crises were viewed either as products of failures of government and anti-poverty policy and lack of resources, compounded by economic dislocation and urbanization, or as strictly private events which a theory of justice for the poor could not influence without becoming unduly intrusive. (Margulies 1996: 1081-82)

47. Debates within legal service programs as to whether to expand to include domestic violence work have typically taken the form of a debate over whether only "victims," typically women - or also accused perpetrators, typically men should be represented. Traditional advocates of legal aid for the poor (both in the United States and overseas) have often raised considerations of equity and non-discrimination as reasons both sides must be represented, while those who identify with the battered women's movement have emphasized the importance of acting in ways that consistently "empower" victims contributing to the problem by representing accused batterers (Abell 1992: 147; Hart 1995).

48. I was referred to this movie by a fellow clinical professor at a clinical theory workshop where we were discussing the challenge of teaching students to empathize with poor people and to understand why some poor women remain loyal to their abusive partners. When I later saw the movie I understood why my colleague (a criminal defense lawyer) liked it. It did not really portray men's emotional cruelty and abusiveness toward women as women, the earmark of most male battering behavior. It made the abusiveness appear to be just another terrible consequence of the general rage and hopelessness of a poor black man.

49. One of the few African-American women battling that denial a decade ago, Beth Richie stated "[w]hile it remains critical that black people continue actively struggling against racism and discrimination, it must not be done at the physical and psychological expense of black women" (Richie 1985: 43). That the denial continues, perhaps to slightly lesser extent, is exemplified in my experience by the lack of attention to domestic violence by local leaders and activists in the poor black communities in the Washington, D.C. area, as well as the obvious racial division in attitudes toward domestic violence which surfaced nationwide in reaction to the verdict in the Simpson case (Butler 1995). The denial is also visible in more academic contexts: For instance, a recent publication by the Maternal and Child Health Bureau summarizing a workshop on the "Impact of Community Violence on African American Children and Families: Collaborative Approaches to Prevention and Intervention," makes no mention of family violence. However it does state: "In the reconceptualization of violence in African-American communities it is important to recognize the role that oppression, unequal opportunities, discrimination, and poverty play in its development and perpetuation. Violence must be viewed as the reaction to the interaction between a dominant and minority culture that depends on the denigration of the African-American group" (Isaacs 1992).

50. Indeed, insofar as perpetrators, as intimate partners, might benefit from their spouse's or partner's income, their undermining of women's economic productivity hurts themselves as well as their victims. Most contemporary families require two incomes to survive (Thurow 1996: 33).

51. The challenge of simultaneously recognizing an individual's victimization while also determining whether to hold him or her responsible for harm $\mathrm{s} / \mathrm{he}$ has committed has been a major topic in recent social and intellectual discourse concerning a series of cases of abuse victims who have attacked their abusers, i.e., the Bobbitt and Menendez cases. On one end of the spectrum, a wave of self- 
described feminist "anti-victimization" advocates solve this dilemma by denying the "victim" status of women, arguing that they are in part responsible for their own victimization (Roiphe 1993; Wolf 1993: 135-216; Abrams 1995: 329-332). A non-feminist and even less sympathetic position is taken by Alan Dershowitz, who has also surprisingly abandoned his role as defender of the accused when it comes to women and children who claim a history of abuse (Dershowitz 1994). Among feminist legal theorists, several voices have called for a more nuanced understanding of abuse victims and perpetrators (Ashe \& Cahn 1994: 166; Cahn \& Meier 1995: 353-56). In this essay, I hope to begin to meet the same challenge in reconciling the simultaneous victim and perpetrator status of poor people of color who abuse their partners.

52. Gary Bellow \& Jeanne Charn (1995: 1633), in responding to Feldman, also acknowledge some stagnation but they offer more concrete, specific and "day-today" solutons al a tocal tevel.

53. Obviously, the right-wing backlash against the social and political "revolution" of the $1960 \mathrm{~s}$ has played a powerful role in smashing leftist and progressive initiatives and political power. However, that does not explain why the movements of the Left have been ineffective in defending themselves ideologically and morally, if not in terms of actual political or economic power (Tomaskey 1996: 99-102, 108-112). Some may argue that the Left has lost credibility because it is too closely identified with welfare, and welfare as a system or policy is remarkably unpopular, even among the poor. In my view, while the critique of welfare may indeed be widespread and even deserved, it cannot explain the disintegration of the Left. The welfare reform movement was not driven by those who wanted to improve ways of liberating and empowering the poor, but rather by those who wanted to blame the poor for their own predicament; the reformers disagreed with the Left on far more than the inefficacy of welfare.

54. I am reminded of the public defender who described work on a homicide case against a woman who had killed her abuser as "God's work," contrasting it to the majority of her cases in which she finds her position as an advocate to be less morally pure. Peter Margulies (1996: 1092-1104) has argued that domestic violence offers revitalization to legal service work in several other ways, including offering a more holistic vision of the lawyer-client relationship, greater "voice" and solidarity for clients, and greater political mobilization.

55. Jody Raphael of the Taylor Institute, and the NOW LDEF, along with the new National Task Force on Women, Welfare and Abuse, has publicized the issue among grassroots programs as well as informing national political figures and organizations. By the summer of 1996, the link had also appeared in "mainstream" organs of the battered women's movement such as the Domestic Violence Report (Friedman 1996: 1) and the Family Violence Prevention Fund Newsletter, as well as other mainstream women's organizations. Higher profile efforts to bring the issue to public and national policymakers' attention are described in section VI below. The domestic violence movement is far from unified on this issue, however. Some advocates have argued against publicization of the new findings concerning domestic violence and welfare, for some of the same reasons the movement historically chose to avoid mentioning poverty and battering in the same breath (see section $\operatorname{IV}(B)(2)(a)$ ).

56. Indeed, it can be argued that in the DOJ statistics, the graduated rise in the rates of domestic violence as income decreases makes it unlikely that it is men's increasing willingness to batter as their income decreases that is reflected: it is hardly plausible that men's rates of abuse would be so directly determined by their income level that rates of abuse would gradually rise in seeming correlation 
with the gradually decreasing income. One would expect instead to see a disjunction between "poor" and "wealthy" populations' rates of battering. A graduated rise is more logically reconciled with the victims' decreasing ability to escape violence, as their income decreases.

57. A far harsher depiction of relations between the sexes in the urban black ghetto community has been offered by some analysts, such as Doug Massey, who states that, through decades of "intense social and economic isolation, segregation has helped to create a nihilistic and violent counterculture sharply at odds with the basic values and goals of a democratic society" (Massey \& Denton 1993: 177). He continues:

[a]ccording to Anderson, by the late 1980s sexual relations in the ghetto had degenerated into a vicious, competitive contest in which young men and women exploited each other with diametrically opposed goals. For young ghetto men, sex had become strictly a means of enhancing status among male peers and of experiencing pleasure at the expense of women ... "status goes to the winner, and sex is prized not as a testament of love but as testimony to control of another human being". (Ibid. 176-77, quoting Anderson, 1990)

The degradation of relations between the sexes in ghetto culture is further exemplified by much rap music which calls women "bitches" good only for sex (ibid.).

On a slightly different front, Julie Blackman has also described a disturbing series of recent conversations with African-Americans in which the beating of children was defended as "black," and non-violence in the family characterized as "white" (Blackman 1996: 4).

58. In an incisive commentary, Lisa Brush argues that synthesizing the concerns of economics and "harm" will strengthen the feminist movement as a whole by weakening class and race divisions and by disarming the critics of "victim-feminism" who will no longer be able to reduce feminism to a purely "moralistic" non-economic cause (Brush 1997: 243). While I share her goal of broadening the focus of the feminist movement, I am less convinced that the "anti-victim-feminism" critics would be moved by feminism's embrace of poverty concerns. Indeed, Brush herself notes that these critics have studiously ignored the many ways the feminist movement has addressed "economic" issues (ibid.: 243).

59. This is not to suggest that we should retreat from holding poor batterers accountable through criminal or other sanctions, an issue which is addressed in section $V(B)(1)$ below. In the individual case in court, where it remains critical to convey the seriousness of the violence and the culpability of the perpetrator, advocacy is not likely to significantly change. My plea for greater understanding is primarily applicable to our struggles to understand battering in sociological, psychological and political or legal dialogues outside the courtroom, and importantly, in our relationships with our clients. However, as suggested in section $V(B)(2)$, a recognition of the intersection between poverty and battering might lead to new policy orientations, e.g., in welfare policy.

60. Labeling of battered women as suffering from "the syndrome," a form of mental disorder, has resulted in the denial of custody and other failures to obtain legal relief (Meier 1993: 1309; Mahoney 1991: 43-49).

61. Thus, Evan Stark (1995: 1004-6) argues that a "coercive control" paradigm better focuses attention on batterers' intentional control of woman than more psychological paradigms such as "battered woman syndrome" or "posttraumatic stress disorder," which tend to focus attention on the victim's "dysfunction." Gondolf and Fisher (1988) reframe victims of domestic violence as "survivors" who persist in seeking safety despite overwhelming pressures. 
62. See notes 42,55 , supra.

63. The extent to which male abuse of women in the family has been historically accepted throughout time and the world is really quite remarkable. Both the Dobashes and Susan Schechter have surveyed the history of officially sanctioned abuse of women in the family in the West (Dobash \& Dobash 1979: 31-74; Schechter 1982: 53-56); for comparisons of domestic violence among cultures and countries, see Fineman and Mykitiuk (1994: 255-346) and Marcus (1994: 11-34).

64. Indeed, it is because patriarchy is socially deeply accepted that battering is still not universally understood to be "immoral," and that the crusade to end domestic violence continues to be fundamentally a moral crusade (Brush 1997: 244-45). In some sense, this understanding of the feminist perspective offers some limited compassion toward batterers, in that it recognizes that men who batter are not necessanly pathological "monsters" but are products of their culture, who believe they are doing the right or justified thing.

65. It is probably no coincidence that the rise of moralism toward the poor over the last decade coexists with an increasing willingness to take action against domestic violence; as discussed above, the moralism of the fight against domestic violence fits easily within that frame. In this essay I am attempting to articulate another means of integrating the "moral" battle against domestic violence into anti-poverty policy, within a framework which is more sympathetic toward the poor, and to which progressives can subscribe.

66. It has not been uncommon for shelters for battered women to require women to quit their jobs and go on welfare, so that an abuser cannot learn the location of the shelter by following her home from the job (Raphael 1996c: n. 149). Clearly, such policies will have to be reconsidered in the wake of current welfare reforms.

67. The extreme hardship exemption is the only "safety net" available for numerous other populations in addition to battered women, such as physically and mentally disabled parents, or elderly grandparent caretakers. Some welfare (and battered women's) advocates have thus perceived battered women to be competing with these populations for the exemption. As described further below, the FVO offers a solution by allowing battered women to receive temporary waivers of work and other requirements, separate and apart from the $10 \%$ hardship exemption cause (Pollack \& Davis 1997: 1082-83).

68. As this article goes to press, a conference committee rejected the technical amendment of the FVO and decided to require a General Accounting Office study instead (Pub L No 105-33, \& 5001(i)). A subsequent attempt, in September 1997 , to enact the change received approval in the Senate (HR $2264 \$ 220$ ), by a 98 to 1 vote, but it again awaits action in a conference committee.

69. A useful overview of the issues in implementation of the FVO at the local level is contained in Pollack and Davis 1997.

\section{REFERENCES}

ABELL, JENNIE (1992) "Women, Violence and the Criminal Law: 'It's the Fundamentals of Being a Lawyer that are at Stake Here'," Queen's Law Journal 17: $147-73$.

ABRAMS, KATHRYN (1995) "Sex Wars Redux: Agency and Coercion in Feminist Legal Theory," Columbia Law Review 95: 304-76.

ADAMS, DAVID (1988) "Treatment Models of Men Who Batter: A Profeminist Analysis." In Feminist Perspectives on Wife Abuse, edited by K. Yllo \& M. Bograd. Calif.: Sage Publications. 
AMMONS, LINDA (1995) "Mules, Madonnas, Babies, Bathwater, Racial Imagery and Stereotypes: The African-American Woman and the Battered Woman Syndrome," Wisconsin Law Review (1995): 1003-80.

ANDERSON, ELIJAH (1990) Streetwise: Race, Class and Change in an Urban Community. Chicago: Univ. of Chicago Press.

ASHE, MARIE, and NAOMI CAHN (1994) "Child Abuse: A Problem for Feminist Theory." In Fineman \& Mykituiuk 1994.

BACHMAN, RONET, and LINDA E. SALTZMAN (1995) Violence Against Women: Estimates from the Redesigned Survey. National Crime Victimization Survey, a Bureau of Justice Statistics Special Report. Washington, D.C.: U.S. Dept. of Justice, Office of Justice Programs, Bureau of Justice Statistics.

BARRY, MARGARET MARTIN (1994) "A Question of Mission: Catholic University Law School's Domestic Violence Clinic," Howard Law Journal 38: 135-61.

BELLOW, GARY, and JEANNE CHARN (1995) "Paths not yet Taken: Some Comments on Fetdman's-Critique Legat-Services-Practice," Georgetown Law Journal 83: 1633-68.

BELLUCK, PAM (1997) "Women's Killers are Very Often Their Partners, A Study Finds," New York Times 31 March: B1, B3.

BLACKMAN, JULIE (1996) "Race Matters: Culture, Negative Culture and Family Violence," Domestic Violence Report (June/July): 4, 15.

BLANKENHORN, DAVID (1995) Fatherless America: Confronting Our Most Urgent Social Problem. New York: BasicBooks.

BROWNE, ANGELA, and SHARI BASSUK (1997) "Intimate Violence in the Lives of Homeless and Poor Housed Women: Prevalence and Patterns in an Ethnically Diverse Sample," American Journal of Orthopsychiatry 67: 261-78.

BRUSH, LISA D. (1997) "Harm, Moralism, and the Struggle for the Soul of Feminism,"Violence Against Women 3: 237-56.

BRYANT, SUSAN, and MARIA ARIAS (1992) "Case Study: A Battered Women's Rights Clinic: Designing a Clinical Program which Encourages a Problem-Solving Vision of Lawyering that Empowers Clients and Community," Washington University Journal of Urban \& Contemporary Law 42: 207-22.

BUTLER, PAUL (1995) "O.J. Reckoning: Rage for a New Justice," Washington Post 8 October: C-1.

CAHN, NAOMI (1992) "Civil Images of Battered Women: The Impact of Domestic Violence on Child Custody Decisions," Vanderbilt Law Review 44: 1041-97.

CAHN, NAOMI, and JOAN MEIER (1995) "Domestic Violence and Feminist Jurisprudence: Towards a New Agenda," Boston University Public Interest Law Journal 4: 339-61.

COONTZ, STEPHANIE (1992) The Way We Never Were: American Families and the Nostalgia Trap. New York: BasicBooks.

CRENSHAW, KIMBERLE (1991) "Mapping the Margins: Intersectionality, Identity Politics, and Violence Against Women of Color," Stanford Law Review 43: 1241-99.

- (1995) "Panel Presentation on Cultural Battery," University of Toledo Law Review 25: 891-902.

CUNNINGHAM, LYNN (1996) Conversation, Associate Professor of Clinical Law, The George Washington University Law School.

DATTA, R.C. (1987) "Women's Education, Family Size and Earnings," Indian Journal of Social Work 48: 325-32.

DAVIES, JILL (1994) "Using Safety Planning as an Approach to Woman-Defined Advocacy." Unpublished paper.

(1996) Interview with author, May. (forthcoming 1997) Woman-Defined Advocacy: Safety Planning for Battered Women (working title). Sage Publications (manuscript on file with author). 
DAVIS, MARTHA F. (1993) Brutal Need: Lawyers and the Welfare Rights Movement, 1960-1973. New Haven: Yale Univ. Press.

DAVIS, MARTHA F., and SUSAN J. KRAHAM (1995) "Protecting Women's Welfare in the Face of Violence," Fordham Urban Law Journal 22: 1141-57.

DAVIS, MARTHA F, PAMELA COUKOS, and RHONDA LEES (1996) Written Testimony of NOW Legal Defense and Education Fund, NOW, New York State, and NOW, New York City Chapter on Proposed Welfare Legislation in Governor's Budget Bill (S.5603/A.8410) before the New York State Senate Committee on Social Services, 5 January (New York City).

DEPARLE, JASON (1996) "The New Contract with America's Poor," New York Times

28 July: E-1.

DERSHOWITZ, ALAN M. (1994) The Abuse Excuse: and Other Copouts: Sobstories and Evasions of Responsibilities. Boston: Little, Brown.

DOBASH, R. EMERSON, and RUSSELL DOBASH (1979) Wiotence-Against Wives. New York: Free Press.

- (1992) Women, Violence and Social Change. New York: Routledge.

DUTTON, MARY ANN (1993) "Understanding Women's Responses to Violence: A Redefinition of the Battered Woman Syndrome," Hofstra Law Review 21: 1191-1242.

DUTTON, MARY ANN, and LISA A. GOODMAN (1994) "Post Traumatic Stress Disorder among Battered Women: Analysis of Legal Implications," Behavioral Sciences \& the Law 12: 215-34.

EATON, MARY (1994) "Abuse by Any Other Name: Feminism, Difference, and Intralesbian Violence." In Fineman \& Mykitiuk 1994.

ENOS, PUALANI (1996) "Prosecuting Battered Mothers: State Laws' Failure to Protect Battered Women and Abused Children," Harvard Women's Law Journal 19: 229-68.

FAMILY VIOLENCE PREVENTION FUND. News from the Homefront. Quarterly Newsletter. San Francisco: The Fund.

FELDMAN, MARC (1995) "Political Lessons: Legal Services for the Poor," Georgetown Law Journal 83: 1529-1632.

FINEMAN, MARTHA A. (1991) "Images of Mothers in Poverty Discourses," Duke Law Journal 1991: 274-95.

- (1994) The Neutered Mother, The Sexuality Family, and Other Twentieth Century Tragedies. New York: Routledge.

FINEMAN, MARTHA A., and ROXANNE MYKITIUK (eds.) (1994) The Public Nature of

Private Violence: The Discovery of Domestic Abuse. New York: Routledge.

FISCHER, KARLA, NEIL VIDMAR, and RENEE ELLIS (1993) "The Culture of Battering and the Role of Mediation in Domestic Violence Cases," SMU Law Review 46: 2117-74.

FORD, RICHARD (1991) "Prosecution as a Power Source: A Note on Empowering Women in Violent Conjugal Relationships," Law \& Society Review 25: 313-34.

(1995) The Indianapolis Domestic Violence Prosecution Experiment. Final Report to the National Institute of Justice. Indianapolis: Indiana University. FRIEDAN, BETTY (1995) "Incorporating Men into the Women's Movement," Georgetown Journal on Fighting Poverty 1(3): 25-27.

FRIEDMAN, LAURA (1995) "Family Cap and Unconstitutional Conditions Doctrine: Scrutinizing a Welfare Woman's Right to Bear Children," Ohio State Law Journal 56: 637-63.

FRIEDMAN, LUCY N. (1996) "Veterans of the War at Home," Domestic Violence Report (June/July): 1, 10.

GELLES, RICHARD, REGINA LACKNER, and GLENN WOLFNER (1994) "Men who Batter: The Risk Markers," Violence Update 4(12): 1-4.

GONDOLF, EDWARD, and ELLEN FISHERS (1988) Battered Women as Survivors: An Alternative to Treating Learned Helplessness. Lexington, Mass.: Lexington Books. 
GONDOLF, EDWARD (1995) "Batterer Intervention: What We Know and Need to Know." Paper presented at the Violence Against Women Research Strategic Planning Workshop, National Institute of Justice, 31 March (on file with author).

GORDON, LINDA (1988) Heroes of Their Own Lives: The Politics and History of Family Violence, Boston 1880-1960. New York: Viking.

1850-1935) Pitied but not Entitled: Single Mothers and the History of Welfare 1850-1935. New York: Free Press.

GORDON, LINDA, and NANCY FRASER (1994) "A Genealogy of Dependency: Tracing a

Keyword of the U.S. Welfare State," Signs 19: 309-36.

GORDON, MALCOLM (ed.) (1996) "Validity of 'Battered Women Syndrome' in Criminal Cases Involving Battered Women," prepared by M.A. Dutton. In The Validity and Use of Evidence Concerning Battering and its Effects in Criminal Trials: Report Responding to Section 40507 of the Violence Against Women Act. Washington, D.C.: U.S. Dept. of Justice, Office of Justice Programs, National Institute of Justice, and U.S. Dept. of Health and Human Services, National Institute of Mental Health.

GUARD, ANARA (1997) Violence and Teen Pregnancy: A Resource Guide for MCH Practitioners. Newton, Mass.: Children's Safety Network, Education Development Center.

HANDLER, JOEL (1994) "Two Years and You're Out," Connecticut Law Review 26: 857-69.

HANDLER, JOEL F., and YEHESKEL HASENFELD (1991) The Moral Construction of Poverty: Welfare Reform in America. Newbury Park, Calif: Sage Publications.

HARRINGTON, MICHAEL (1963) The Other America: Poverty in the United States. Baltimore: Penguin Books.

HARRIS, ANGELA (1991) "Race and Essentialism in Feminist Legal Theory." In Feminist Legal Theory: Readings in Law and Gender, edited by $\mathrm{K}$. Bartlett \& R. Kennedy. Boulder, Colo.: Westview Press.

HART, BARBARA (1992) "State Codes on Domestic Violence: Analysis, Commentary and Recommendations," Juvenile \& Family Court Journal 43: 3-81.

- (1995) Letter to author, July.

HARTMANN, HEIDI, and ROBERTA SPALTER-ROTH (1994) "Reducing Welfare's Stigma: Policies that Build Upon Commonalities Among Women," Connecticut Law Review 26: 901-11.

HERMAN, JUDITH (1992) Trauma and Recovery. New York: BasicBooks.

HEYMAN, STEVEN J. (1991) "The First Duty of Government: Protection, Liberty and the Fourteenth Amendment," Duke Law Journal 41: 507-71.

ISAACS, M.R. (1992) The Impact of Community Violence on the African-American Children and Families: Collaborative Approaches to Prevention and Intervention. Arlington, Va.: National Center for Education in Maternal and Child Health.

KAMINER, WENDY (1995) It's All the Rage: Crime and Culture. Reading, Mass.: Addison-Wesley.

KEMP, ANITA, BONNIE L. GREEN, CHRISTINE HOVANITZ, and EDNA I. RAWLINGS (1991) "Post-traumatic Stress Disorder in Battered Women: A Shelter Sample," Journal of Traumatic Stress 4: 137-48.

$-(1995)$ "Incidents and Correlates of Posttraumatic Stress Disorder in Battered Women: Shelter and Community Samples," Journal of Interpersonal Violence 10: 43-45.

KINSLEY, MICHAEL (1995) "The Ultimate Block Grant," The New Yorker 29 May:

KLEIN, ANDREW (1997) "Editorial," National Bulletin on Domestic Violence Prevention 3(January): 2. 
KLEN, CATHERINE F., and LESLYE E. ORLOFF (1993) "Providing Legal Protection for Battered Women: An Analysis of State Statutes and Case Law," Hofstra Law Review 21: 801-1189. KURZ, DEMIE (1995) For Richer, For Poorer: Mothers Confront Divorce. New York: Routledge. LEGAL SERVICES OF NORTHERN VIRGINIA (1995) "Women and Families in Crisis," Arlington, Va.: Arlington County Bar Foundation.

LITTLETON, CHRISTINE (1989) "Women's Experience and the Problem of Transition," University of Chicago Legal Forum (1989): 23-57. University of Chicago Legal Forum (1989): $23-57$.
LOPEZ, JERRY (1996) Comments in Panel Discussion, Joint Poverty and Clinical
Section Workshop, AALS Annual Meeting, San Antonio, Tex.

LÖTTER, J.M. (1977) "The Effect of Urbanization and Education on the Fertility of Blacks in South Africa," Humanitas (South Africa) 4: 21-28.

LYNN, LAURENCE, JR. (1993) "Ending Welfare Reform as we Know it," The American

Prospect 15(Fall): 83-92.

MAHONEY, MARTHA (1991) "Legal Images of Battered Women: Redefining the Issue of Separation," Michigan Law Review 90: 1-94.

- (1994) "Victimization or Oppression? Women's Lives, Violence, and Agency."

In Fineman \& Mykitiuk 1994.

MARCUS, ISABEL (1994) "Reframing Domestic Violence: Terrorism in the Home." In

Fineman \& Mykitiuk 1994.

MARGULIES, PETER (1996) "Representation of Domestic Violence Survivors as a New Paradigm of Poverty Law: In Search of Access, Connection, Voice," George Washington Law Review 63: 1071-1104. Making of the Underclass. Cambridge, Mass.: Harvard Univ. Press.

MATSUDA, MARI J. (1988) "When the First Quail Calls: Multiple Consciousness as Jurisprudential Method," Speech, Yale Law School Conference on Women of

MEIER, JOAN (1993) "Notes from the Underground: Integrating Psychological and Legal Perspectives on Domestic Violence in Theory and Practice," Hofstra Law Review 21: 1295-1366.

MERRYMAN, MITHRA (1993) "A Survey of Domestic Violence Programs in Legal Education," New England Law Review 28: 383-452.

MICCIO, KRISTIAN (1995) "In the Name of Mothers and Children: Deconstructing the Myth of the Passive Battered Mother and the 'Protected Child' in Child Neglect

Proceedings," Albany Law Review 58: 1087-1107.

MINK, GWENDOLYN (1994) "Welfare Reform in Historical Perspective," Connecticut Law Review 26: 879-99. 1168-72.

MILLS, LINDA G. (1996) "On the Other Side of Silence: Affective Lawyering for Intimate Abuse," Cornell Law Review 81: 1225-63.

MINOW, MARTHA (1994) "The Welfare of Single Mothers and Their Children," Connecticut Law Review 26: 817-42.

MOYNIHAN, DANIEL PATRICK (1990) Speech before the U.S. Senate. Congressional Record 101st Cong., 2d Sess., Daily ed., 3 October.

MURPHY, PATRICIA A. (1997) "Recovering From the Effects of Domestic Violence: Implications for Welfare Reform Policy," Law \& Policy 19: 169-82.

MURRAY, CHARLES (1984) Losing Ground: American Social Policy 1950-1980. New York: BasicBooks. York: BasicBooks.
NATIONAL COUNCIL OF JUVENILE AND FAMILY COURT JUDGES (1995) "Family
Violence in Child Custody Statutes: An Analysis of State Codes and Legal Practice," Family Law Quarterly 29: 197-227. 
NATIONAL WOMAN ABUSE PREVENTION PROJECT (n.d.) "General Facts About Domestic Violence," Domestic Violence Fact Sheets. Washington, D.C.: The Project.

NEW YORK STATE DEPARTMENT OF LABOR (1996) "Report to the New York State Legislature on Employees Separated from Employment Due to Domestic Violence." 15 January. Albany: New York Dept. of Labor.

PAYMAR, MICHAEL (1993) Violent No More: Helping Men End Domestic Abuse. California: Sage Publications.

PLECK, ELIZABETH (1987) Domestic Tyranny: The Making of Social Policy Against Family Violence from Colonial Times to the Present. New York: Oxford Univ. Press.

POLLACK, WENDY (1996) "Twice Victimized - Domestic Violence and Welfare 'Reform,"' Clearinghouse Review 30: 329-41.

POHACK, WENDY, and MARTHA E DAVIS (1997) "The Eamily Option of the Personal Responsibility and Work Opportunity Reconciliation Act of 1996: Interpretation and Implementation," Clearinghouse Review 30: 1079-1100.

POWELl, JOHN A. (1993) "Race and Poverty: A New Focus for Legal Services," Clearinghouse Review 27: 299-309.

RAPHAEL, JODY (1995) "Domestic Violence: Telling the Untold Welfare-to-Work Story." Unpublished report. Chicago: Taylor Institute.

- (1996a) "Prisoners of Abuse: Domestic Violence and Welfare Receipt."

Unpublished report. Chicago: Taylor Institute.

(1996b) Memorandum to author, 26 February.

- (1996c) "Domestic Violence and Welfare Receipt: Toward a New Feminist

Theory of Welfare Dependency," Harvard Women's Law Journal 19: 201-27.

(1996d) Memorandum to author, 25 June.

(1997) Memorandum to author, 19 May.

RAPHAEL, JODY, and RICHARD TOLMAN (1997) "Trapped by Poverty/Trapped by Abuse: New Evidence Documenting the Relationship between Domestic Violence and Welfare." Unpublished report. Chicago: Taylor Institute.

RICHIE, BETH (1985) "Battered Black Women: A Challenge for the Black Community," The Black Scholar (March/April): 40-44.

(1996) "Violence in the Lives of African American Women: A Focus Group Study." New York: Institute on Violence, Inc. Unpublished, on file with author. ROIPHE, KATIE (1993) The Morning After: Sex, Fear, and Feminism on Campus. Boston: Little Brown.

RUTTENBERG, MIRIAM H. (1994) “A Feminist Critique of Mandatory Arrest: An Analysis of Race and Gender in Domestic Violence Policy," American University Journal of Gender and the Law 2: 171-99.

SAUNDERS, DANIEL (1994) "Posttraumatic Stress Symptoms Profiles of Battered Women: A Comparison of Services in Two Settings," Violence and Victims 9: $31-44$.

SCHECHTER, SUSAN (1982) Women and Male Violence: The Visions and Struggles of the Battered Women's Movement. Boston: South End Press.

SCHECHTER, SUSAN, and ANN JONES (1992) When Love Goes Wrong. New York: Harper Collins.

SCHEER, ROBERT (1995) "Gingrich, Savaging Welfare, Is on a Fool's Errand," Los Angeles Times 28 November: B-9.

SCHNEIDER, ELIZABETH (1986) “Describing and Changing: Women's Self-Defense Work and the Problem of Expert Testimony on Battering," Women's Rights Law Report 9: 195-222.

(1992) "Particularity and Generality: Challenges of Feminist Theory and Practice in Work on Woman-Abuse," NYU Law Review 67: 520-68.

(1993) "Feminism and the False Dichotomy of Victimization and Agency," New York Law School Review 38: 387-99. 
YE, KATHARINE Q. (1996) "Dole is Confronted on His View of Welfare," New ork Times 31 May: A-20. LALA, DONNA (1996) Letter from the Fifty States, 30 October. uman Services to Governors RMAN, ARLOC (1994) Whild Poverty. Boston: Beacon Press.

RMAN, LAWRENCE w. (1992) "The Influence of Criminology on Criminal Law: valuating Arrests for Misdemeanor Domestic Violence," Journal of Criminal Law nd Criminology 83: 1-45. RK, EVAN (1993) Case Report to District of Columbia Superior Court in Brown v Tutt, DR 2029-92c (on file with author).

- (1995) "Re-Presenting Woman Battering: From Battered Woman Syndrome to Coercive Control," Albany Law Review 58: 973-1026.

RAIGHT OUT OF BROOKtY) The Future of Cap: HBO Video. Videocassette.

IUROW, LESTER C. (1996) The Fulure of Capitalism: How Today's Economic Forces

Shape Tomorrow's World. New York: William Morrow. SLMAN, RICH M., and JEFFREY L. EDLESON (1995) "Intervention
A Review of Research." In Understanding Partner Violence: Prevalence, Causes,
Consequences, and Solutions, edited by S. Stith \& M. Straus. Minn.: National Council on Family Relations.

OMASKEY, MICHAEL (1996) Left for Dead: The Life, Death, and Possible Resurrection of Progressive Politics in America. New York: Free Press.

RUBEK, LOUISE (1995) "The Worst of Times ... And the Best of Times? Lawyering

for Poor Clients Today," Fordham Urban Law Journal 22. C.: [Congress]. J.S. OFFICE OF THE PRESTEEN (1) Attorney General." Guidelines to States for Implementing the Family Violence Provisions. 3 October.

(1996b) "National Domestic Violence Awareness Month." Proclamation 6927.

Federal Register 61: 52677.

VALLIN, JACQUES (1973) "Influence de Divers Facteurs Économiques et Sociaux sur la Fécondité de L'Algérie," Population (Paris) 28: 87-42.

voBEJDA, BARBara (1996) "After 60 Years, a Basic Shift in Philosophy," Washington Post 1 Aug: A-1.

WALD, MICHAEL S. (1975) "State Intervention on Behalf of 'Neglected' Children: A Search for Realistic Standards," Stanford Law Review 27: 985-1040.

(1976) "State Intervention on Behalf of Montoring the Status of Children in Foster Care and Termination of Parental Rights," Stanford Law Review 28: 625-706.

WEEKS, GREG, and CAROL WEBSTER (1993) Over Half of the Women on Public Assistance in Washington State Reported Physical or Sexual Abuse as Adults. Unpublished report of the Washington State Institute for Public Policy, Evergreen State College, Olympia, October. green State College, Olympia, October.
wHTE, LUC1E (1993) "No Exit: Rethinking 'Welfare Dependency' from a Different
Ground," Georgetown Law Journal 81: 1961-2002.

(1994) "On the "Consensus' to End Welfare: Where are the Women's Voices?"

Connecticut Law Review 26: 843-56.

Connecticut Law Review 26: 843-56.
wILLAMS, LUCY (1992) "The Ideology of Division: Behavior Modification Welfare
Reform Proposals," Yale Law Journal 102: 719-46.

WOLF, NAOMI (1993) Fire with Fire: the New Female Power and How it will Change the 21st Century. New York: Random House.

WOODS, LAURIE (1982) “Challenges Facing Legal Services in the 80's," Clearinghouse

Review 16: 26-31. 
(1978) "Litigation on Behalf of Battered Women,"Women's Rights Law Reporter 5: 7-32.

ZORZA, JOAN (1991) "Woman Battering: a Major Cause of Homelessness," Clearinghouse Review 25: 421-29.

(1992) "The Criminal Law of Misdemeanor Domestic Violence, 1970-1990," Journal of Criminal Law \& Criminology 83: 46-72.

(1996a) Memorandum to author, 14 June.

(1996b) "Protecting the Children in Custody: Disputes When One Parent

Abuses the Other," Clearinghouse Review April: 1113-27.

\section{CASES CITED}

Harris v McRae, 448 US 297, 100 S Ct 2671, 65 L Ed 2d 784 (1980).

King v Smith, 392 US 309, 88 S Ct 2128, 20 L Ed 2d 118 (1968).

Lewis v Martin, 397 US 552, $90 \mathrm{~S} \mathrm{Ct} \mathrm{1282,} 25$ L Ed 2d 561 (1970).

Maher v Roe, 432 US 464, 97 S Ct 2376, 53 L Ed 2d 284 (1977).

\section{LEGISLATION CITED}

45 CFR \& 232.42 (1996).

Balanced Budget Act, Pub L No 105-33, 111 Stat 251 (1997).

House of Representatives Bill 4, 104th Cong, 1st Sess (1995).

House of Representatives Bill 1950, 105th Cong, 1st Sess (1997).

House of Representatives Bill 2264, 105th Cong, 1st Sess (1997).

Personal Responsibility and Work Opportunity Reconciliation Act, Pub L No $104-193,110$ Stat 2105 (1996) (as codified at 42 USC $\$ 601-617,6696$ ).

Senate Bill 671, 105th Cong, 1st Sess (1997).

Violence Against Women Act, see Title IV of Violent Crime Control and Law Enforcement Act 1994.

Violence Crime Control and Law Enforcement Act, Pub L No 103-322, 108 Stat 1796 (1994). 